Supporting information

\title{
Stable Chiral Ruthenium Complex Catalyst Based on Polymer Ionic Liquid for Asymmetric Transfer Hydrogenation of Aliphatic Ketones in Water
}

\author{
Xinjuan $\mathrm{Li}^{\mathrm{a}, *}$, Yanping Sun ${ }^{\mathrm{a}}$, Shangyue Wanga ${ }^{\mathrm{a}}$, Xianbin Jia ${ }^{\mathrm{a}, *}$ \\ a Henan Key Laboratory of Green Chemistry, Collaborative Innovation Center of \\ Henan Province for Green Manufacturing of Fine Chemicals, Key Laboratory of \\ Green Chemical Media and Reactions, Ministry of Education, School of Chemistry \\ and Chemical Engineering, Henan Normal University, Xinxiang, 453007, P. R. China, \\ Correspondence to: Xinjuan Li(E-mail:) xinjuanli2009@163.com \\ Xianbin Jia (E-mail:) axbjia@163.com
}

Supporting information contains 29 pages (S1-S29)

Supporting information contains 5 tables (Table S1-S5)

Supporting information contains 13 figures (Figure S1-Figure S13) 


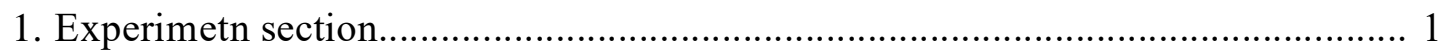

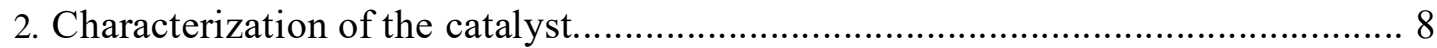

3. Catalysts used in asymmetric transfer hydrogenation reaction.............................13

4. General procedure for the chiral derivatization................................................. 13

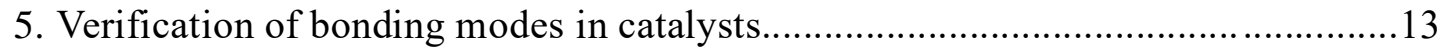

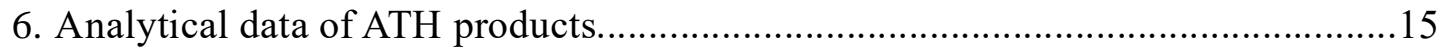

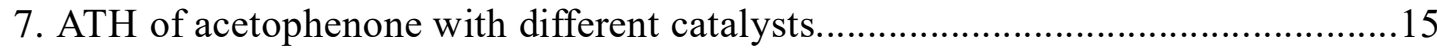

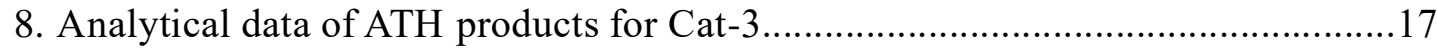




\section{Experimental section}

Materials and Reagents. Methacrylicacid ( $>98 \%$, MAA, Aldin, China) was purifified by distillation under pressure. Azobis(isobutyronitrile) $(>98 \%$, AIBN, Tianjin 
chemical reagent co, China) was recrystallized in ethanol. PIL-1 was prepared using previously described methods ${ }^{[1]}$, and other chemical reagents were used as-received condition.

Methods. ${ }^{1} \mathrm{H}$ NMR spectra were measured on a Bruker $400 \mathrm{MHz}$ NMR spectrometer. A Thermo FLASH 1112 elemental analyzer was used to determine the elemental analysis. The IR measurements were carried out on a Fourier transform infrared spectrometer (Nicolet 94 NEXUS). HPLC method was performed on an Agilent TM 1100. The molecular weight and molecular weight distribution $(\mathrm{PDI}=\mathrm{Mw} / \mathrm{Mn})$ of the synthesized polymer samples were determined by gel permeation chromatography (GPC) equipped with a Waters 1515 apparatus, DMF was used as eluent, the flflow rate was $1.0 \mathrm{~mL} . \mathrm{min}$, and polystyrene samples were used as standards. Transmission electron microscopy (JEOL-2010, $200 \mathrm{kV}$ ) and field emission scanning electron microscopy (NovaNano SEM450) were used to characterize the morphology of the catalyst. DSC was performed on a custom-made PCT-1A thermal analysis system. XPS spectra were obtained on a VG ESCALAB MK II spectrograph.

\section{Preparation of catalysts}

\subsection{Synthesis of PILs}

PIL was synthesized by the polyepichlorohydrin $(\mathrm{PECH})$ and methylimidazole. As a typical experiment ${ }^{[1]}$, PECH $(1 \mathrm{~g}, 0.50 \mathrm{mmol})$ was added into a one-neck round bottom flask $(100 \mathrm{~mL})$, after being degassed for $30 \mathrm{~min}$, methylimidazole $(0.023 \mathrm{~g}$, $0.28 \mathrm{mmol}$ ) was added by syringe, the mole ratio of PECH to methylimidazole was 
1.8:1.0. Stirring until completely dissolved, the flask was sealed and immersed into an oil bath at $80^{\circ} \mathrm{C}$ for $10 \mathrm{~h}$, and then the crude product (PIL-1) was collected by sediment in ether, washed several times with ether until no small molecule impurity was found and dried at $60^{\circ} \mathrm{C}$ under vacuum for $48 \mathrm{~h}$.

The PIL-2 with partial $\mathrm{Cl}^{-}$and partial $\left[\mathrm{NTf}_{2}\right]^{-}$was prepared by partial ion exchange with PIL-1. PIL-1 (29.30 g, $0.067 \mathrm{mmol})$ and LiNTf $2(9.62 \mathrm{~g}, 0.034 \mathrm{mmol})$ were dissolved in $100 \mathrm{~mL}$ distilled water and formed a clear mixture solution, with stirring at $25^{\circ} \mathrm{C}$ for $5 \mathrm{~h}$, the insoluble oily substance was formed and collected by centrifugation, the crude product was washed with water and ether respectively, and dried at $60^{\circ} \mathrm{C}$ under vacuum to use. The yield was $91 \%$.

The PIL-3 was prepared by partial ion exchange with PIL-1. PIL-1 (29.30 g, $0.067 \mathrm{mmol})$ and $\operatorname{LiNTf}_{2}(14.43 \mathrm{~g}, 0.051 \mathrm{mmol})$ were dissolved in $100 \mathrm{~mL}$ distilled water and formed a clear mixture solution, with stirring at $25^{\circ} \mathrm{C}$ for $5 \mathrm{~h}$, the insoluble oily substance was formed and collected by centrifugation, the crude product was washed with water and ether respectively, and dried at $60^{\circ} \mathrm{C}$ under vacuum to use. The yield was $93 \%$.

The PIL-4 was prepared by full ion exchange with PIL-1. PIL-1 (29.30 g, 0.067 mmol) and $\operatorname{LiNTf}_{2}(22.96 \mathrm{~g}, 0.08 \mathrm{mmol})$ were dissolved in $100 \mathrm{~mL}$ distilled water and formed a clear mixture solution, with stirring at $25^{\circ} \mathrm{C}$ for $5 \mathrm{~h}$, the insoluble oily substance was formed and collected by centrifugation, the crude product was washed 
with water and ether respectively, and dried at $60^{\circ} \mathrm{C}$ under vacuum to use. The yield was $91 \%$.

\subsection{Synthesis of polymerizable chiral ligand (1R,}

2R)-N-p-vinyl-1,2-diphenylethylenediamine (V-TsDPEN)

$1 \mathrm{~g}(1 \mathrm{R}, 2 \mathrm{R})-1,2$-diphenylethylenediamine was added to $100 \mathrm{~mL}$ round-bottom flask, and $25 \mathrm{~mL} \mathrm{CH} \mathrm{Cl}_{2}$ was added to dissolve it. After that, 20 drops of triethylamine were added into the flask, and then $1 \mathrm{~g}$ styrene sulfonyl chloride $/ 5 \mathrm{~mL}$ $\mathrm{CH}_{2} \mathrm{Cl}_{2}$ was added to it in ice-water bath, stirred overnight at room temperature, insoluble substances were found. After extraction and filtration, washing with $5 \%$ $\mathrm{NaOH}$ solution, drying, filtering, rotary steaming and dissolving with ether. The ether solution was obtained by extraction and filtration, and then $1 \mathrm{~mL}$ concentrated hydrochloric acid was added to the ether solution to obtain white precipitation. The white solid was filtered and washed with $5 \% \mathrm{NaOH}$ aqueous solution. The white solid was extracted three times with $\mathrm{CH}_{2} \mathrm{Cl}_{2}$ and combined with organic phase. The solvent was removed by rotating evaporation. V-TsDPEN was obtained after drying for $48 \mathrm{~h}$ in $62 \%$ yield.

\subsection{Synthesis of V-TsDPEN-Ru}

The chiral monomer V-TsDPEN $0.756 \mathrm{~g}$ was added in a $100 \mathrm{~mL}$ round bottom flask, and then $40 \mathrm{~mL}$ anhydrous dichloromethane was added to dissolve it. $20.61 \mathrm{~g}$ $\left[\mathrm{RuCl}_{2}(\mathrm{p}\right.$-cymene)] which was dissolved in $20 \mathrm{~mL}$ anhydrous dichloromethane was added the flask. After reaction for $10 \mathrm{~h}$ in argon atmosphere at room temperature, the 
solvent was removed by Spin evaporation. A mixed solvent of dichloromethane/ether $=1 / 1$ was added to remove the surplus $\left[\mathrm{RuCl}_{2}(\mathrm{p}\right.$-cymene $\left.)\right]$ by stirring filtration. The filtrate was concentrated and precipitated in n-hexane. The product was filtered and washed with $n$-hexane. The product was vacuum dried at $25^{\circ} \mathrm{C}$ for $24 \mathrm{~h}$ with the yield of $84.1 \%$.

\subsection{Synthesis of copolymer 1 and 2}

Chiral monomer V-TsDPEN-Ru (3 mmol) and methacrylic acid (0.26 g, $3 \mathrm{mmol})$ were added to a $50 \mathrm{~mL}$ round bottom flask in turn. $6 \mathrm{~mL}$ DMF was added to the flask for ultrasonic dissolution. AIBN (4.92 $\mathrm{mg}, 0.06 \mathrm{mmol})$ was added after 5 minutes of argon gas introduction. After 30 minutes of argon gas introduction, the flask was sealed and the oil bath reacted for $48 \mathrm{~h}$ at $75^{\circ} \mathrm{C}$. After the reaction stopped, a large number of white precipitates were obtained by precipitation in $60 \mathrm{~mL}$ ethanol. After centrifugation, the precipitates were washed repeatedly with anhydrous ethanol to remove the unpolymerized monomers. The white solid products were obtained by vacuum drying at $40^{\circ} \mathrm{C}$ for $48 \mathrm{~h}$. The product was labeled as random copolymer 2 with a yield of $88 \%$.

Chiral monomers of V-TsDPEN (1.13 g, $3 \mathrm{mmol})$ and methacrylic acid $(0.26 \mathrm{~g}$, $3 \mathrm{mmol}$ ) was copolymerization to obtained the copolymer 1 according to the above same way.

\subsection{Synthesis of catalysts}

The $0.247 \mathrm{~mL}$ ammonia water was injected into $50 \mathrm{~mL}$ ethanol solution with a 
syringe volume. Ethanol solution containing $0.5 \mathrm{wt} \%$ ammonia water (complex solvent) was prepared. The amplitude of sound wave of the NC ultrasonic cleaner was set at $40 \%$, and the complex solvent was put into the ultrasonic cleaner for 30 minutes. Accurately random copolymer $1(0.9 \mathrm{mmol}, 0.21 \mathrm{~g})$ in $3 \mathrm{~mL}$ DMSO solution, and PIL-1 $(1.8 \mathrm{mmol})$ in $2 \mathrm{~mL}$ DMSO solution, was mixed and add them to the complex solution by dropping tube under the condition of ultrasound. A large number of PIL complexes precipitate quickly, and then the dropping is completed by ultrasound for 30 minutes, and then filter them. The impurities were removed by precipitation, ethanol washing and vacuum drying for $24 \mathrm{~h}$ at $40^{\circ} \mathrm{C}$. The yield of PIL complex was $73 \%$.

PIL complex $(0.2 \mathrm{mmol}, 0.2 \mathrm{~g})$ was added to $50 \mathrm{~mL}$ round-bottom flask, $20 \mathrm{~mL}$ dichloromethane was added, and then $\left[\mathrm{RuCl}_{2} \text { (p-cymene) }\right]_{2}(0.1 \mathrm{mmol}, 0.061 \mathrm{~g})$ was weighed, dissolved in $5 \mathrm{~mL}$ dichloromethane, then added to round-bottom flask, and reacted at $40^{\circ} \mathrm{C}$ for $24 \mathrm{~h}$ under argon. The product was collected by centrifugation and washed in Soxhlet extractor until ruthenium-free leaching. Cat-1 was obtained by putting the product in a vacuum drying chamber at $40^{\circ} \mathrm{C}$ for $24 \mathrm{~h}$ with the yield of $95 \%$.

The preparation method of Cat-2 is similar to that of Cat-1. Firstly, Ethanol solution containing $0.5 \mathrm{wt} \%$ ammonia water (complex solvent) was prepared. And then, random copolymer $2(0.9 \mathrm{mmol}, 0.21 \mathrm{~g})$ in $3 \mathrm{~mL}$ DMSO, PIL-1 (1.8 mmol, $1.8 \mathrm{~g})$ in $2 \mathrm{~mL}$ DMSO, were mixed evenly and was added to the complex solution under ultrasound. The yield of the Cat-2 was $75 \%$. 
The synthesis of Cat-3, Cat- 4 and Cat-5 is similar to Cat-2 expect using PIL-2 or

PIL-3 and PIL-4 not PIL-1. The yields of Cat-3, Cat-4 and Cat-5 were 69\%, 61\% and $73 \%$ respectively.

2. Characterization of the catalysts.
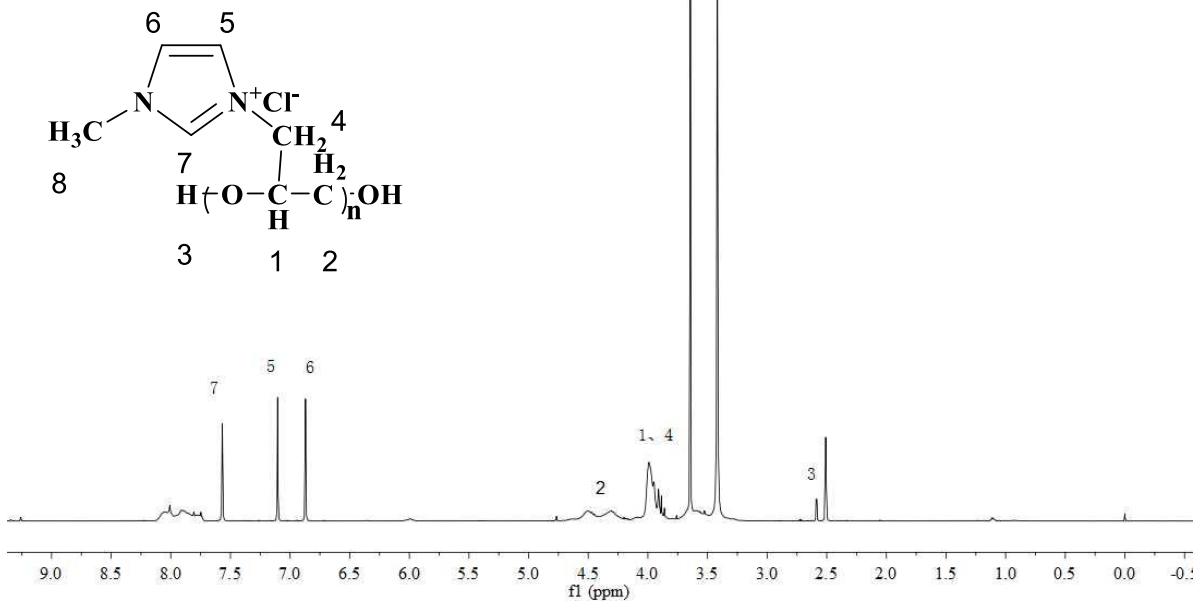

Figure. S1 ${ }^{1} \mathrm{H}$ NMR of PIL-1 in DMSO-d6. 


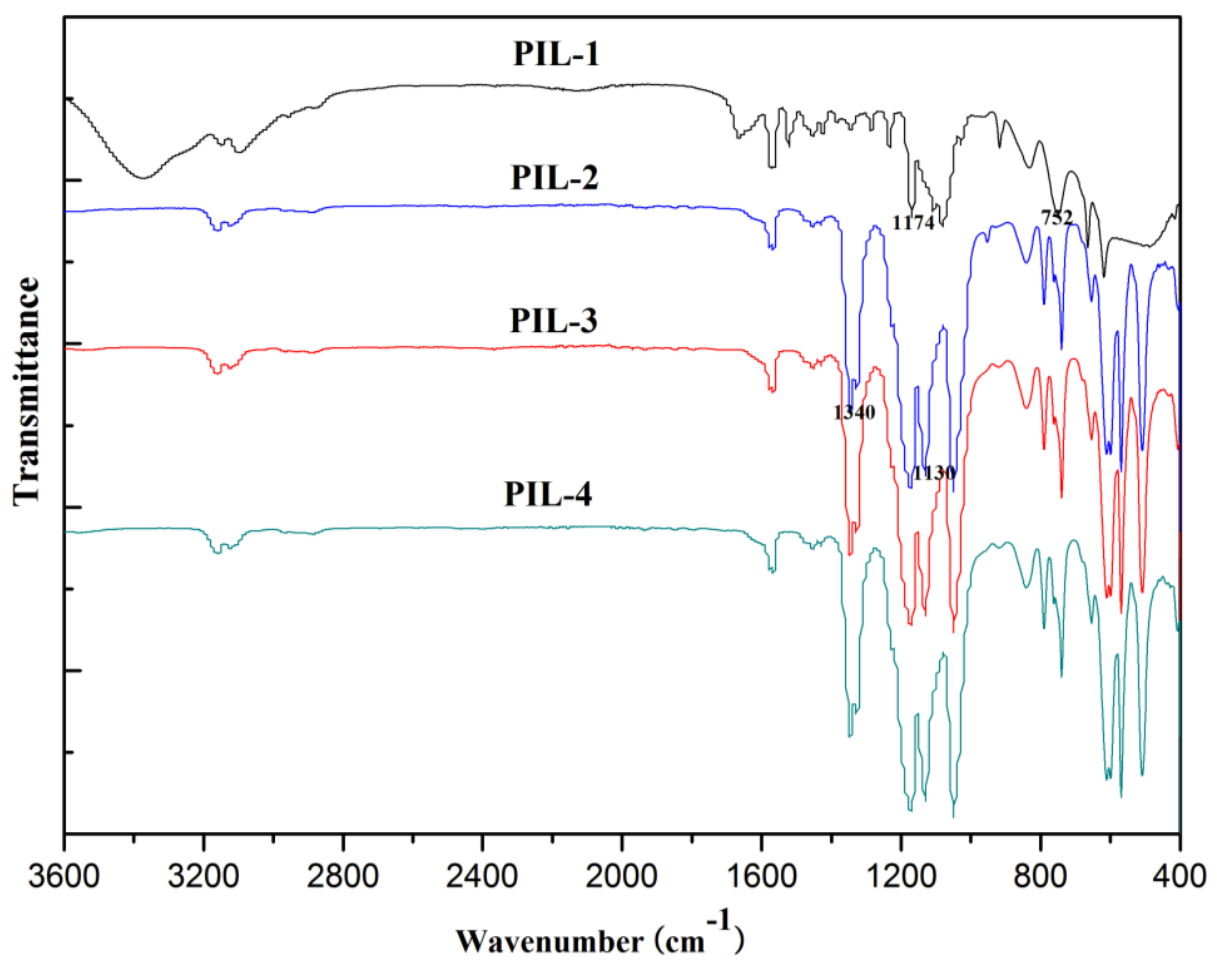

Figure. S2 Fourier transform infrared (FT-IR) spectra of PILs.

The molecular weight of PECH was 1000 . The FT-IR spectra of the PIL-1 revealed the presence of the characteristic peak corresponding to $\mathrm{C}-\mathrm{O}$ bond stretching vibration around $1174 \mathrm{~cm}^{-1}$, it proved that a large number of ether linkages exited in the polymer chains (Fig. S2). C-Cl bond in the $\mathrm{CH}_{2} \mathrm{Cl}$ group stretching vibration was around $750 \mathrm{~cm}^{-1}$. A band at 2958 3200 $\mathrm{cm}^{-1}$ appeared in the FT-IR spectrum, which was the characteristic stretching vibration of the $\mathrm{C}-\mathrm{H}$ band. The spectra around 1340 $\mathrm{cm}^{-1}$ and $1130 \mathrm{~cm}^{-1}$ belongs to the $\mathrm{S}=\mathrm{O}$ bond of $\left[\mathrm{NTf}_{2}\right]^{-}$, which proves the exchange between $\mathrm{Cl}^{-}$and $\left(\mathrm{NTf}_{2}\right)^{-}$. From DSC result, $\mathrm{PIL}$ were liquid above room temperature with the low glass transition temperature $\left(\operatorname{Tg}<0^{\circ} \mathrm{C}\right)$.

Table. S1 Tg of PILs from DSC results and $\mathrm{Cl}^{-}$content of PILs from ion chromatography.

$\begin{array}{lllll}\text { PIL } & \text { PIL-1 } & \text { PIL-2 } & \text { PIL-3 } & \text { PIL-4 }\end{array}$




\begin{tabular}{|c|c|c|c|c|}
\hline $\operatorname{Tg}\left({ }^{\circ} \mathrm{C}\right)$ & -15.61 & -10.02 & -57.06 & -61.70 \\
\hline $\mathrm{Cl}^{-}$content $(\mathrm{mg} / \mathrm{kg})$ & 35.83 & 24.67 & 21.47 & 0 \\
\hline
\end{tabular}

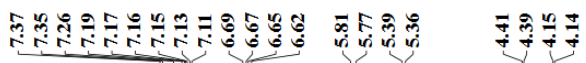

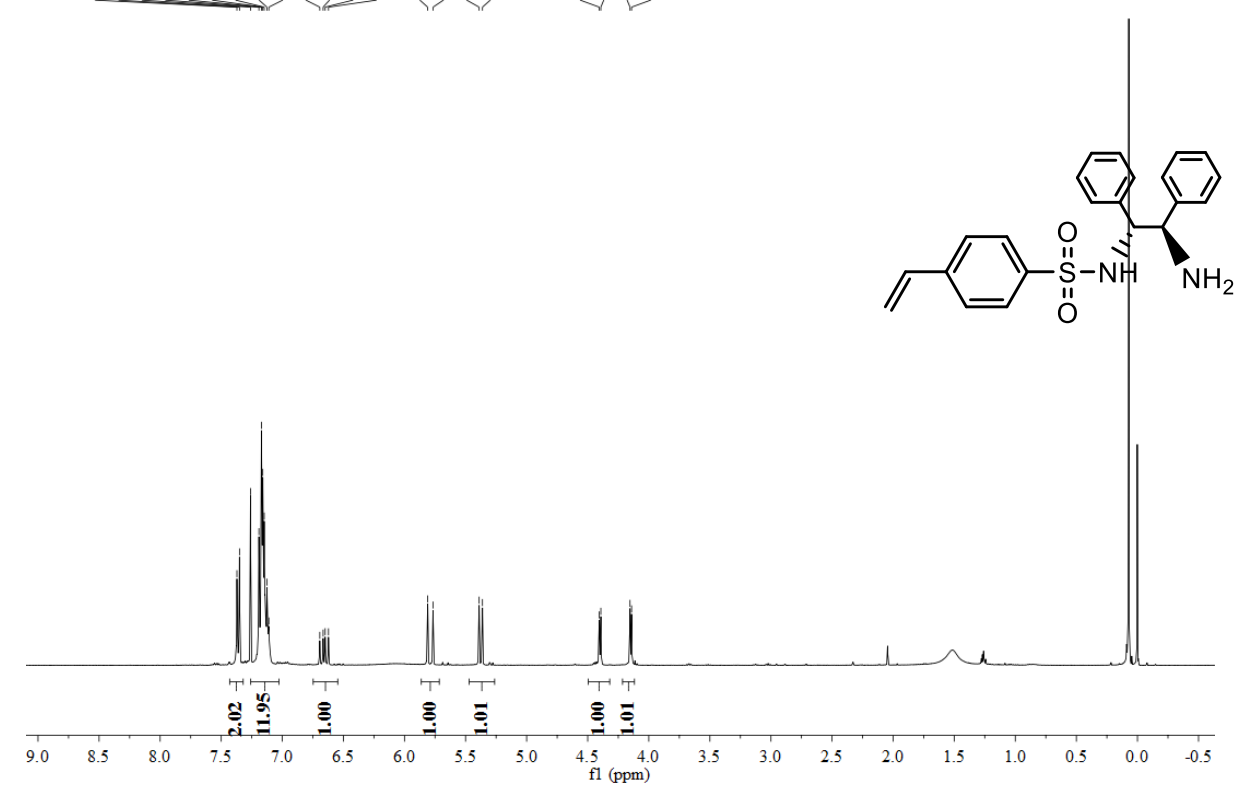

Figure. $\mathrm{S} 3{ }^{1} \mathrm{H}$ NMR of V-TsDPEN in $\mathrm{CDCl}_{3}$.

${ }^{1} \mathrm{H} \mathrm{NMR}\left(400 \mathrm{MHz}, \mathrm{CDCl}_{3}\right) \delta 7.36(\mathrm{~d}, \mathrm{~J}=8.5 \mathrm{~Hz}, 2 \mathrm{H}), 7.26-7.03(\mathrm{~m}, 12 \mathrm{H}), 6.66$ $(\mathrm{dd}, \mathrm{J}=17.6,10.9 \mathrm{~Hz}, 1 \mathrm{H}), 5.79(\mathrm{~d}, \mathrm{~J}=17.6 \mathrm{~Hz}, 1 \mathrm{H}), 5.38(\mathrm{~d}, \mathrm{~J}=10.9 \mathrm{~Hz}, 1 \mathrm{H}), 4.40$ $(\mathrm{d}, \mathrm{J}=5.0 \mathrm{~Hz}, 1 \mathrm{H}), 4.15(\mathrm{~d}, \mathrm{~J}=5.0 \mathrm{~Hz}, 1 \mathrm{H})$. 


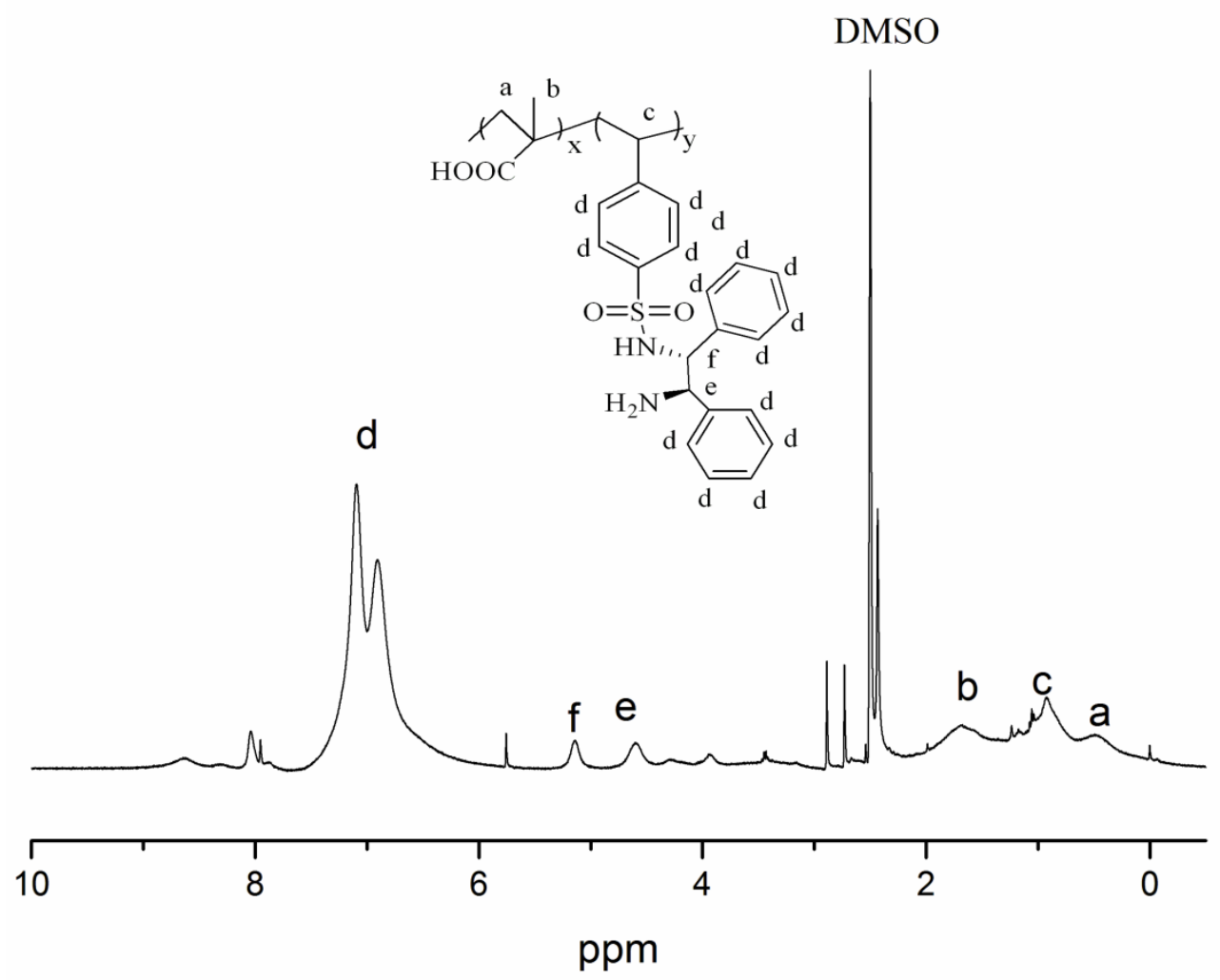

Figure.S4 ${ }^{1} \mathrm{H}$ NMR spectrum of copolymer 1 in DMSO-d 6 .

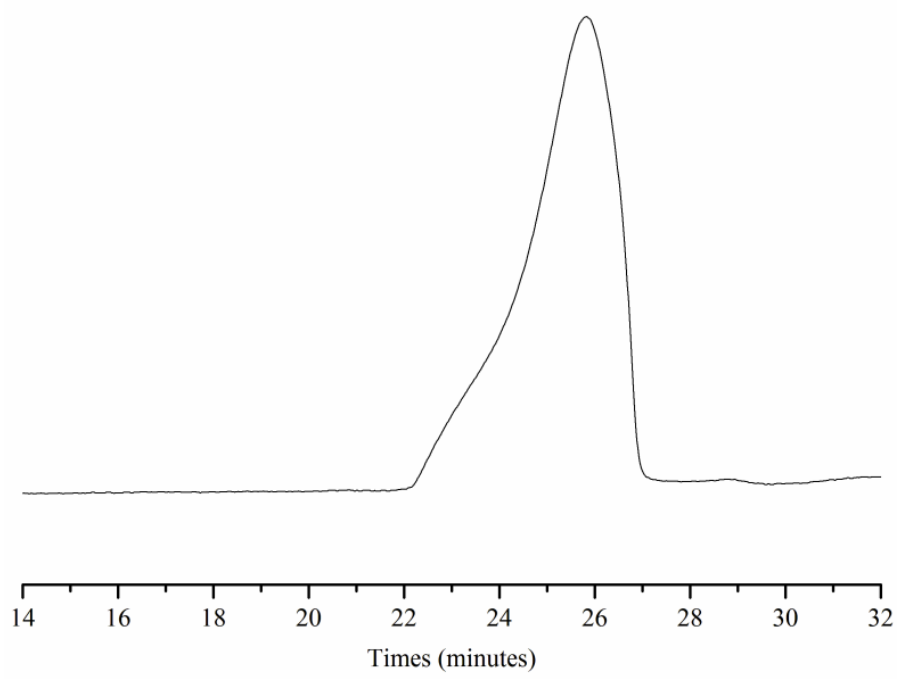

Figure. S5 GPC chromatogram of copolymer 1 in DMF. 


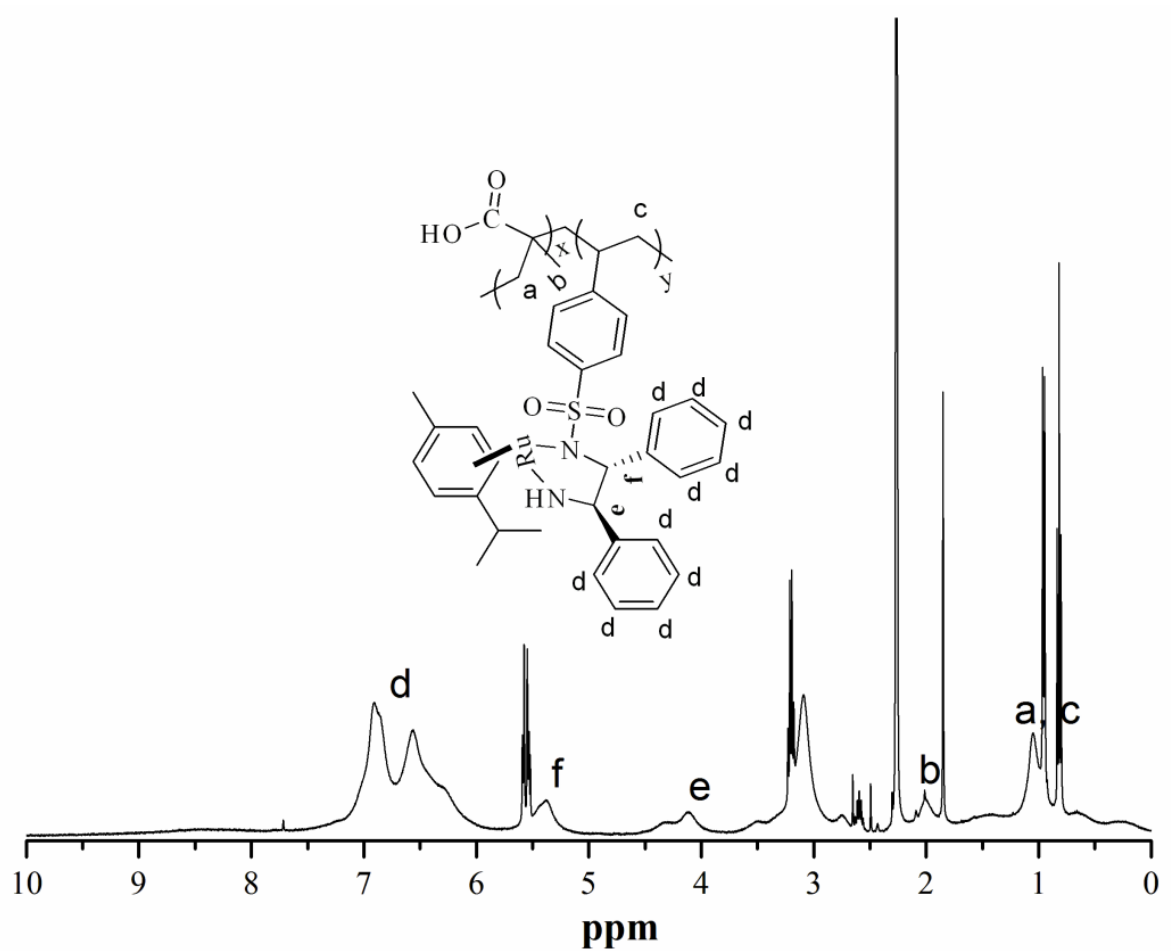

Figure. S6 ${ }^{1} \mathrm{H}$ NMR spectrum of copolymer 2 in DMSO-d6.

Table. S2 Elemental analysis results of catalysts.

\begin{tabular}{ccccc}
\hline Catalysts & $\mathrm{C}$ & $\mathrm{N}$ & $\mathrm{H}$ & $\mathrm{S}$ \\
\hline Cat-1 & 53.00 & 3.75 & 5.46 & 2.06 \\
Cat-2 & 47.90 & 6.34 & 5.08 & 3.54 \\
Cat-3 & 42.15 & 7.64 & 4.64 & 3.15 \\
Cat-4 & 35.06 & 8.42 & 3.67 & 2.77 \\
Cat-5 & 45.63 & 7.14 & 4.67 & 1.92 \\
\hline
\end{tabular}

Table. S3 Proportion of catalyst and its Ru loading.

\begin{tabular}{cccc}
\hline Catalysts & $\begin{array}{c}\text { PIL/copolymer } \\
(\mathrm{mol}) \text { (theroy) }\end{array}$ & $\begin{array}{c}\text { PIL/copolymer (mol } \\
\text { ratio) } \\
(\text { elemental analysis) }\end{array}$ & $\begin{array}{c}\text { Ru loading (\%) } \\
\text { (ICP) }\end{array}$ \\
\hline Cat-1 & $2 / 1$ & $1.21: 1^{\mathrm{a}}$ & 5.24 \\
\hline
\end{tabular}




\begin{tabular}{cccc}
\hline Cat-2 & $2 / 1$ & $1.21: 1^{\mathrm{b}}$ & 4.21 \\
Cat-3 & $2 / 1$ & $1.14: 1^{\mathrm{b}}$ & 5.61 \\
Cat-4 & $2 / 1$ & $1.42: 1^{\mathrm{b}}$ & 4.82 \\
Cat-5 & $2 / 1$ & $1.13: 1^{\mathrm{b}}$ & 5.21 \\
Cat-1 ${ }^{\mathrm{c}}$ & & & 4.15 \\
Cat-3 $^{\mathrm{d}}$ & & & 5.42 \\
\hline
\end{tabular}

${ }^{\mathrm{a}}$ Calculation of $\mathrm{N}$ molar ratio of PIL and copolymer based on elemental analysis of catalysts in table S2, N molar contents of chiral copolymers were calculated acccording to the S content of catalysts, ${ }^{b}$ Calculation of $\mathrm{N}$ molar ratio of PIL and copolymer based on elemental analysis of catalysts in table S2, N molar contents of chiral copolymers were calculated acccording to the $\mathrm{Ru}$ content of catalysts, ${ }^{\mathrm{c}}$ after 4 cycles for Cat-1, ${ }^{\mathrm{d}}$ after 9 cycles for Cat-3.

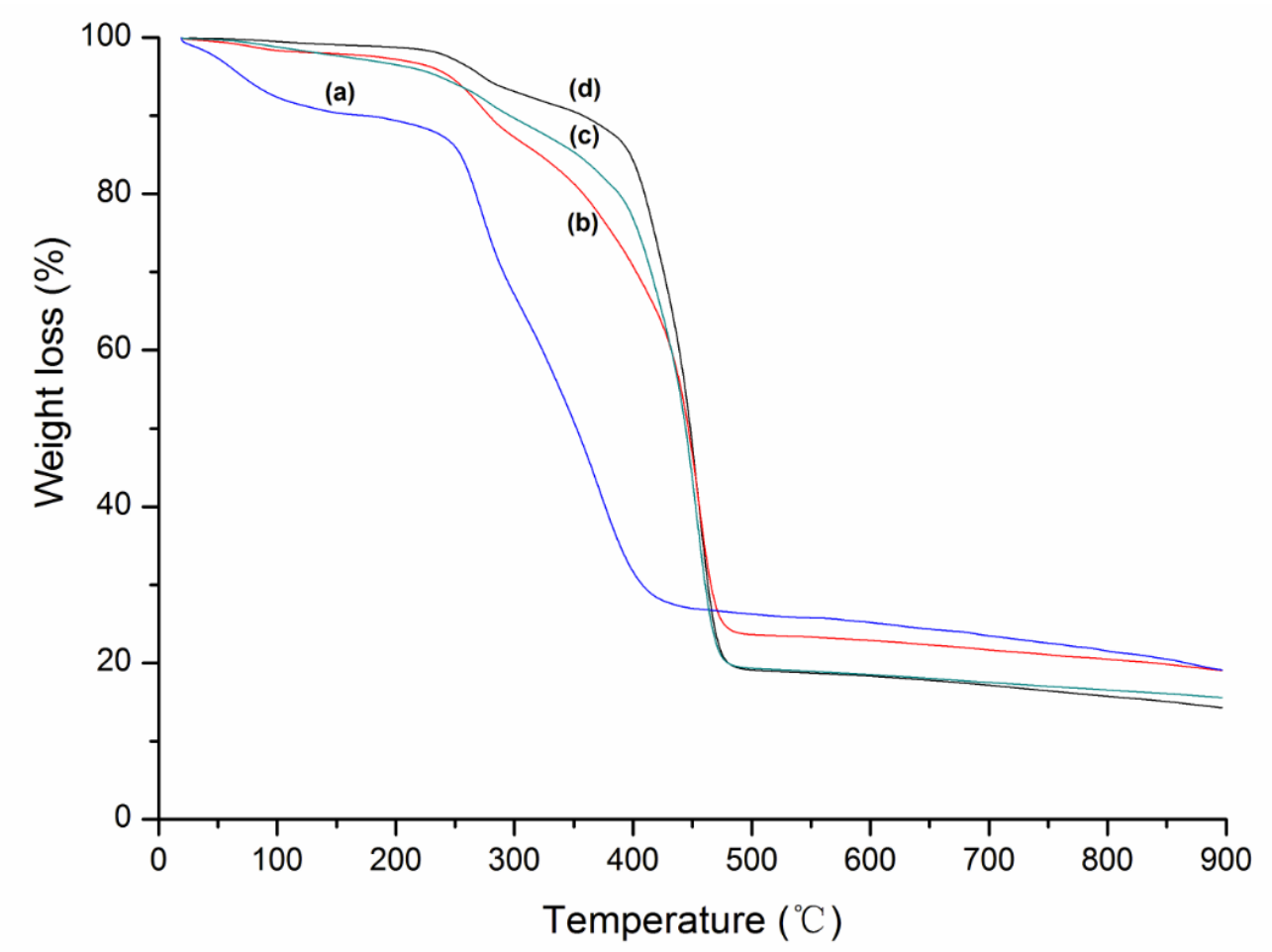

Figure. S7 Thermogravimetric curves of (a) Cat-2, (b) Cat-3, (c) Cat-4, and (d) Cat-5. Test conditions: in the air, the temperature was raised from room temperature to $900^{\circ} \mathrm{C}$ at the rate of $10^{\circ} \mathrm{C} / \mathrm{min}$.

Table. S4 EDS analyses results (wt.\%) on catalyst surfaces from SEM.

\begin{tabular}{ccccccc}
\hline Catalysts & $\mathrm{C}$ & $\mathrm{N}$ & $\mathrm{Cl}$ & $\mathrm{F}$ & $\mathrm{S}$ & $\mathrm{Ru}$ \\
\hline Cat-1 & $27.94 \pm 4.59$ & $6.25 \pm 3.54$ & $1.63 \pm 0.32$ & 0 & $15.43 \pm 1.82$ & $7.97 \pm 3.08$ \\
\hline
\end{tabular}




\begin{tabular}{ccccccc}
\hline Cat-2 & $27.83 \pm 4.03$ & $7.64 \pm 3.26$ & $1.58 \pm 0.42$ & 0 & $14.21 \pm 1.50$ & $14.76 \pm 3.10$ \\
Cat-3 & $29.98 \pm 4.24$ & $3.91 \pm 3.55$ & $0.96 \pm 0.70$ & $10.55 \pm 2.19$ & $21.73 \pm 2.21$ & $13.64 \pm 3.02$ \\
Cat-4 & $25.90 \pm 3.84$ & $7.01 \pm 2.76$ & $0.69 \pm 0.11$ & $11.50 \pm 2.23$ & $25.29 \pm 1.95$ & $17.71 \pm 3.06$ \\
Cat-5 & $26.09 \pm 3.91$ & $5.06 \pm 3.12$ & 0 & $13.66 \pm 2.45$ & $33.06 \pm 2.04$ & $13.36 \pm 3.21$ \\
\hline
\end{tabular}

\section{Catalysts used in asymmetric transfer hydrogenation reaction}

catalyst and $0.5 \mathrm{~mL}$ solvent was added into the centrifugal tube. The catalyst was evenly dispersed in the solvent by ultrasound. Formic acid (1.65 mmol, $62 \mathrm{uL}$ ), triethylamine $(1.35 \mathrm{mmol}, 187 \mathrm{uL})$ and acetone $(0.5 \mathrm{mmol})$ were added into the centrifugal tube respectively. After the reaction was completed, the catalyst was recovered by centrifugation and extracted by ethyl acetate. The organic phase was washed with saturated $\mathrm{NaCl}$ solution. The organic phase was dried with anhydrous $\mathrm{MgSO}_{4}$, filtered and rotated, and the product was vacuum dried at $30^{\circ} \mathrm{C}$ for $24 \mathrm{~h}$.

\section{General procedure for the chiral derivatization}

In a flame-dried Schlenk-flask, the alcohol/amine $(0.1 \mathrm{mmol})$ was dissolved in anhydrous $\mathrm{CH}_{2} \mathrm{Cl}_{2}(1 \mathrm{~mL})$. Et $3 \mathrm{~N}(0.15 \mathrm{mmol}, 21 \mu \mathrm{L})$ and $(S)$-Mosher's acid chloride $(0.12 \mathrm{mmol}, 22 \mu \mathrm{L})$ were added and the reaction mixture was stirred at $25^{\circ} \mathrm{C}$. After completion, $5 \mathrm{~mL} \mathrm{CH}_{2} \mathrm{Cl}_{2}$ was added and the organic phase was successively washed with $0.5 \mathrm{M} \mathrm{Na}_{2} \mathrm{CO}_{3}$ and water, dried over $\mathrm{Na}_{2} \mathrm{SO}_{4}$ and concentrated in vacuo. The enantiomeric composition was analysed by ${ }^{19} \mathrm{~F}$ NMR measurement.

\section{Verification of bonding modes in catalysts}

Firstly, Ethanol solution containing $0.5 \mathrm{wt} \%$ ammonia water (complex solvent) was prepared. And then, random copolymer $2(0.9 \mathrm{mmol})$ in $3 \mathrm{~mL} \mathrm{DMSO},\left[\mathrm{RuCl}_{2}\right.$ 
(p-cymene) $]_{2}(0.9 \mathrm{mmol})$ in $2 \mathrm{~mL}$ DMSO, were mixed evenly and was added to the complex solution under ultrasound. The product was characterized by IR, as shown in Figure S5. The characteristic peak corresponding to $\mathrm{C}=\mathrm{O}$ bond (at $1710 \mathrm{~cm}^{-1}$ and $1653 \mathrm{~cm}^{-1}$ ) in the $\mathrm{COOH}$ group for copolymer 2 dispeared, which indicated that there was obvious complexation between carboxylate of the copolymer and metal $\mathrm{Ru}$.

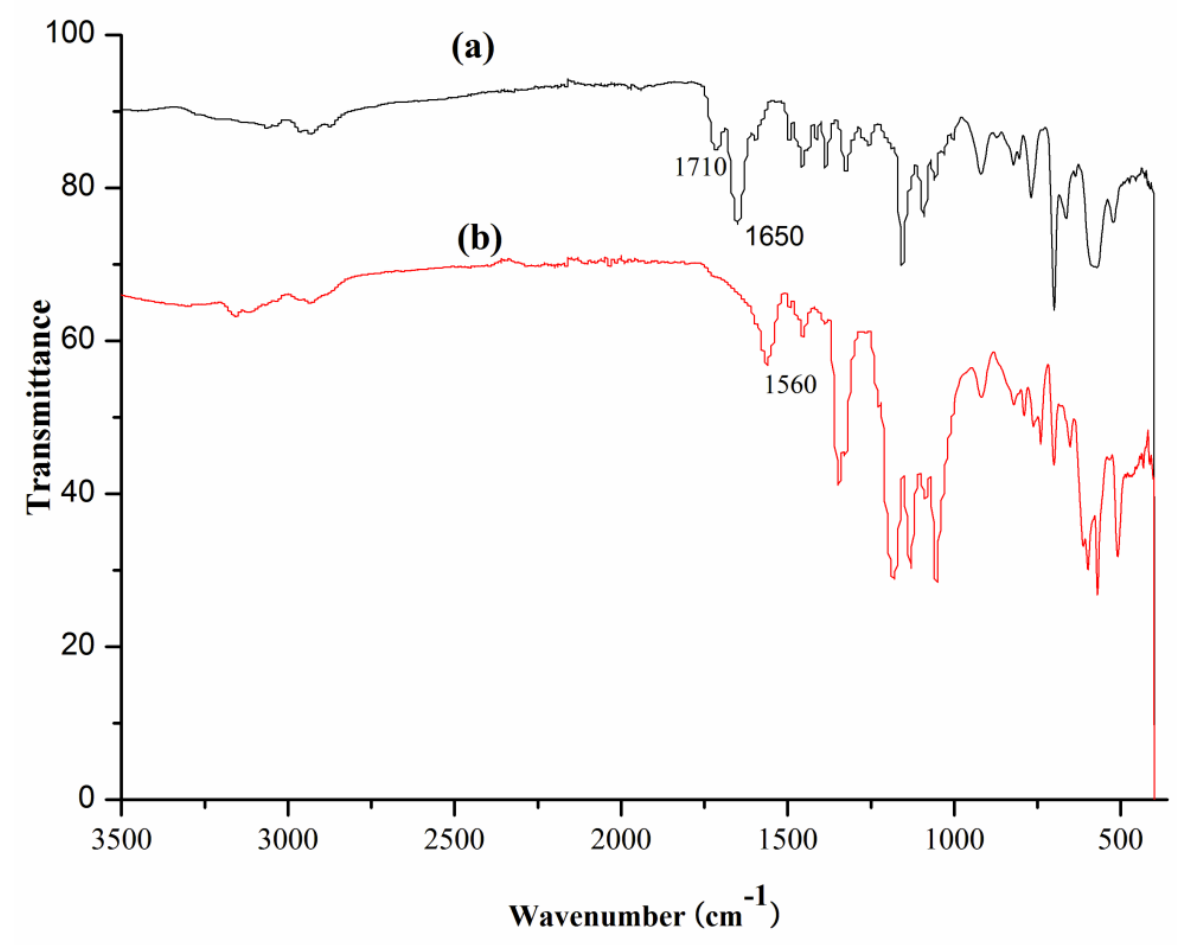

Figure. S8 Fourier transform infrared (FT-IR ) spectra (a) copolymer 2 and (b) copolymer 2 compounded with $\left[\mathrm{RuCl}_{2} \text { (p-cymene) }\right]_{2}$ in ethanolamine solution. 


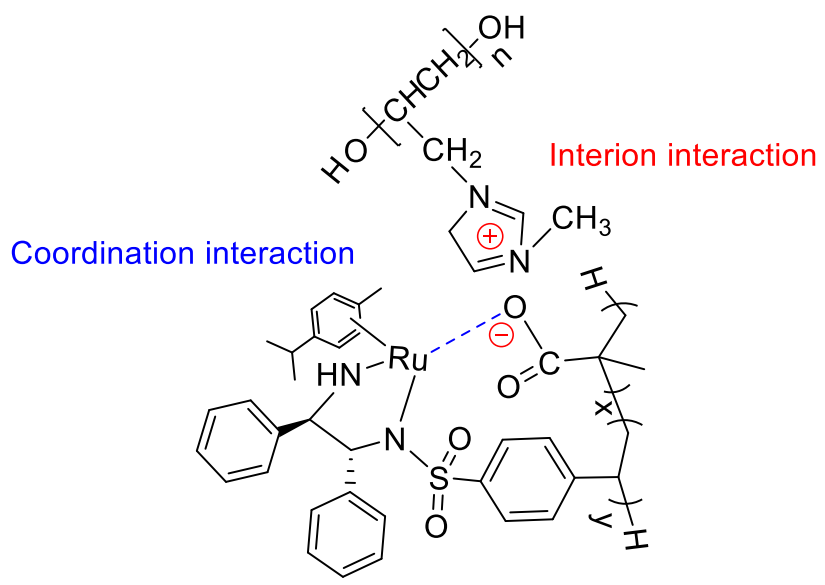

Scheme. S1 Possible formation mechanism of the catalyst was stable by the coordination interaction and interion interaction.

\section{Adsorption of octanone in catalysts}

The peaks belongs to $\mathrm{C}-\mathrm{H}$ stretching vibration region $\left(3000-2700 \mathrm{~cm}^{-1}\right)$ and stretching vibration of carbonyl group at $1750 \mathrm{~cm}^{-1}$ was observed in $1: 1(\mathrm{v} / \mathrm{v})$ of octanone and $\mathrm{D}_{2} \mathrm{O}$ mixing solution (Fig. S6). After adding Cat-2 to octanone and $\mathrm{D}_{2} \mathrm{O}$ solution, the peaks attributable to alkyl ketones did not change significantly. However, After adding the other catalysts (Cat-3, Cat-4 and Cat-5), the peaks of octanone almost completely disappeared. The results show that these catalysts can effectively adsorb alkyl ketone substrates in water. 


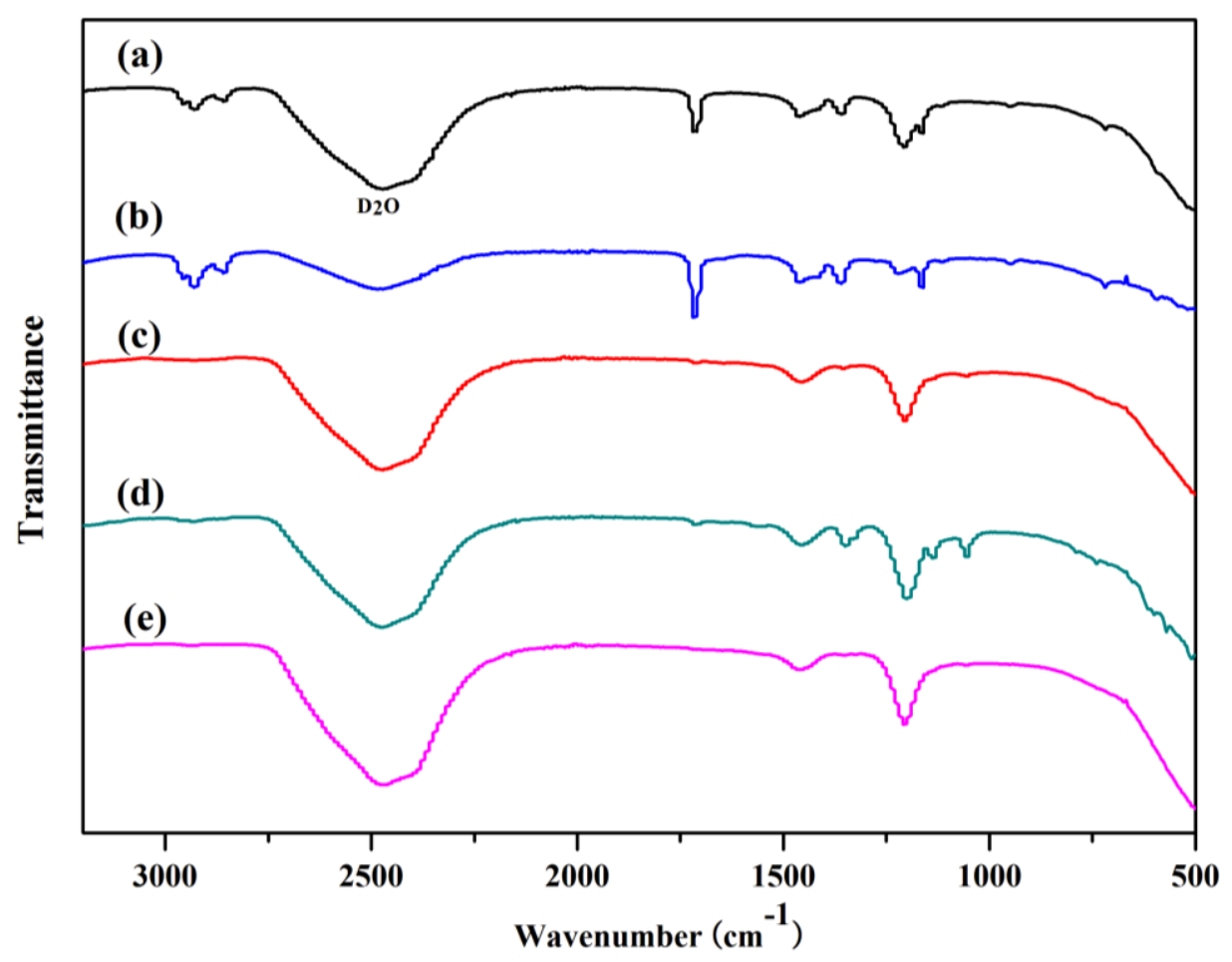

Figure. S9 Fourier transform infrared (FT-IR ) spectra (a) octanone in $\mathrm{D}_{2} \mathrm{O}$, (b) after adding Cat-2 to octanone and $\mathrm{D}_{2} \mathrm{O}$ solution, (c) after adding Cat-3 to octanone and $\mathrm{D}_{2} \mathrm{O}$ solution, (d)after adding Cat- 4 to octanone and $\mathrm{D}_{2} \mathrm{O}$ solution, (e) after adding Cat-5 to octanone and $\mathrm{D}_{2} \mathrm{O}$ solution.

\section{ATH of acetophenone with different catalysts}

Table. S5 ATH of acetophenone with different catalysts.

\begin{tabular}{cccc} 
& & \\
\hline Catalysts $^{\mathrm{a}}$ & Time $(\mathrm{h})$ & $\%$ ee $^{\mathrm{c}}$ \\
\hline Cat-2 & 17 & 97 & 96 \\
Cat-3 & 24 & 96 & 95 \\
Cat-4 & 22 & 97 & 94 \\
Cat-5 & 25 & 94 & 95 \\
\hline
\end{tabular}

${ }^{a}$ Reaction conditions: $0.00004 \mathrm{mmol}$ of $\mathrm{Ru}, 1 \mathrm{~mL}$ of $\mathrm{H}_{2} \mathrm{O}, 2 \mathrm{mmol}$ of HCOONa, $0.04 \mathrm{mmol}$ of ketone, $40{ }^{\circ} \mathrm{C}, \mathrm{s} / \mathrm{c}=1000 .{ }^{\mathrm{b}}$ Conversion was determined by ${ }^{1} \mathrm{H}$ NMR. ${ }^{\mathrm{c}}$ Enantiomeric excess was determined by HPLC. 

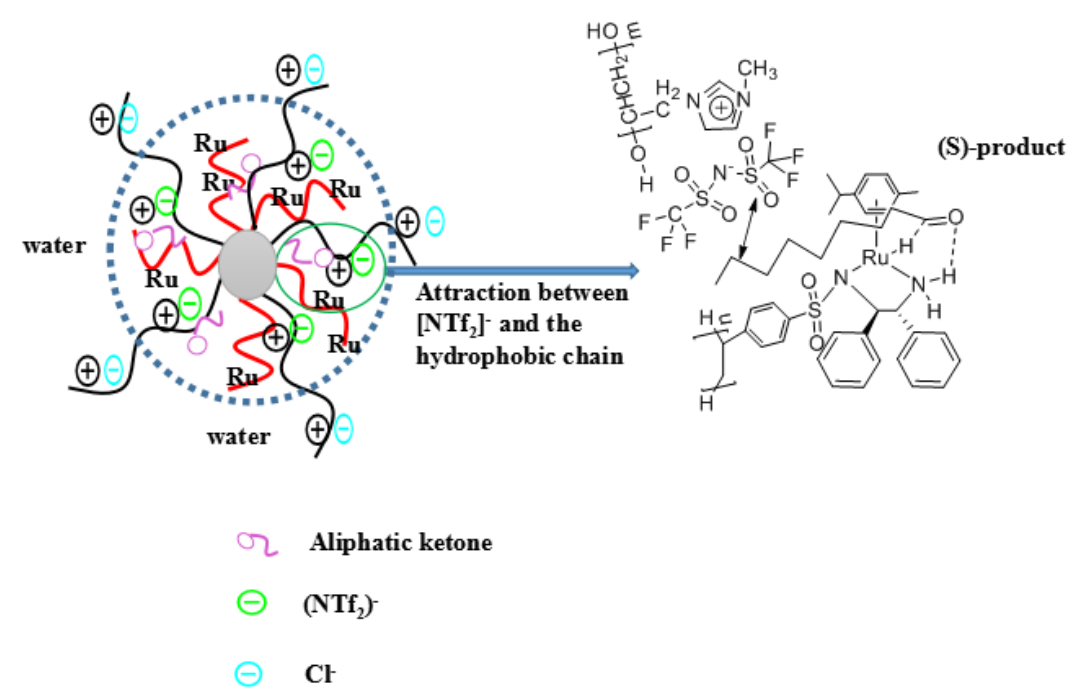

Figure. S10 Proposed mechanism of reduction of aliphatic ketones with Cat-3.

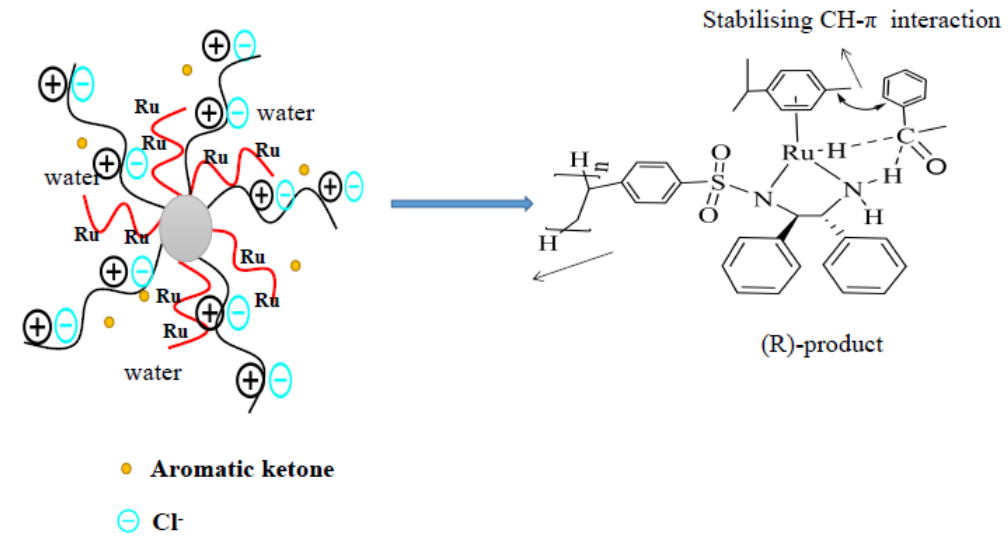

Figure. S11 Proposed mechanism of reduction of Aromatic ketones in the Cat-2. 


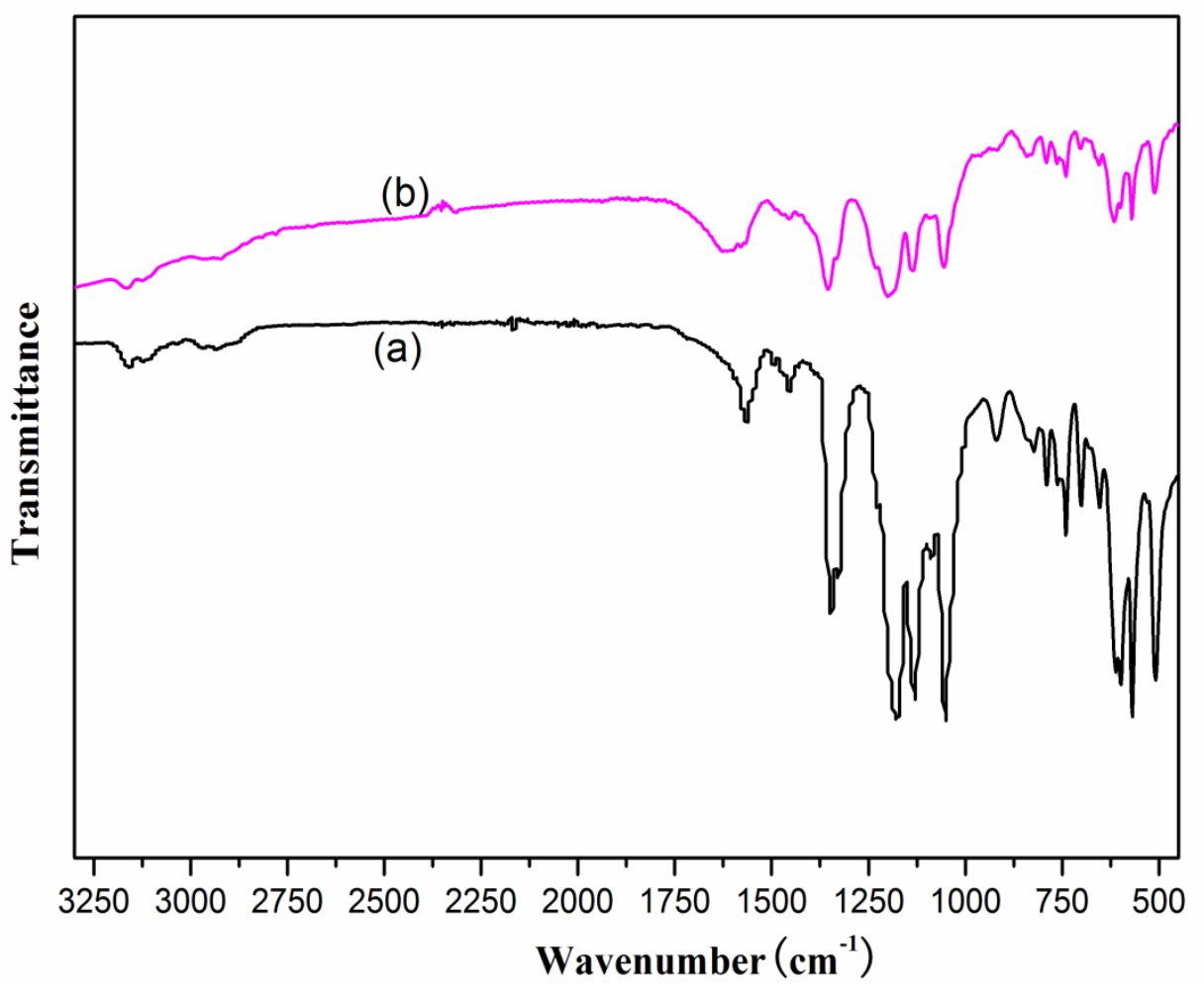

Figure. S12 Fourier transform infrared (FT-IR) spectra (a) Cat-3 before catalysis, (b) Cat-3 after nine times of catalyst circulation.

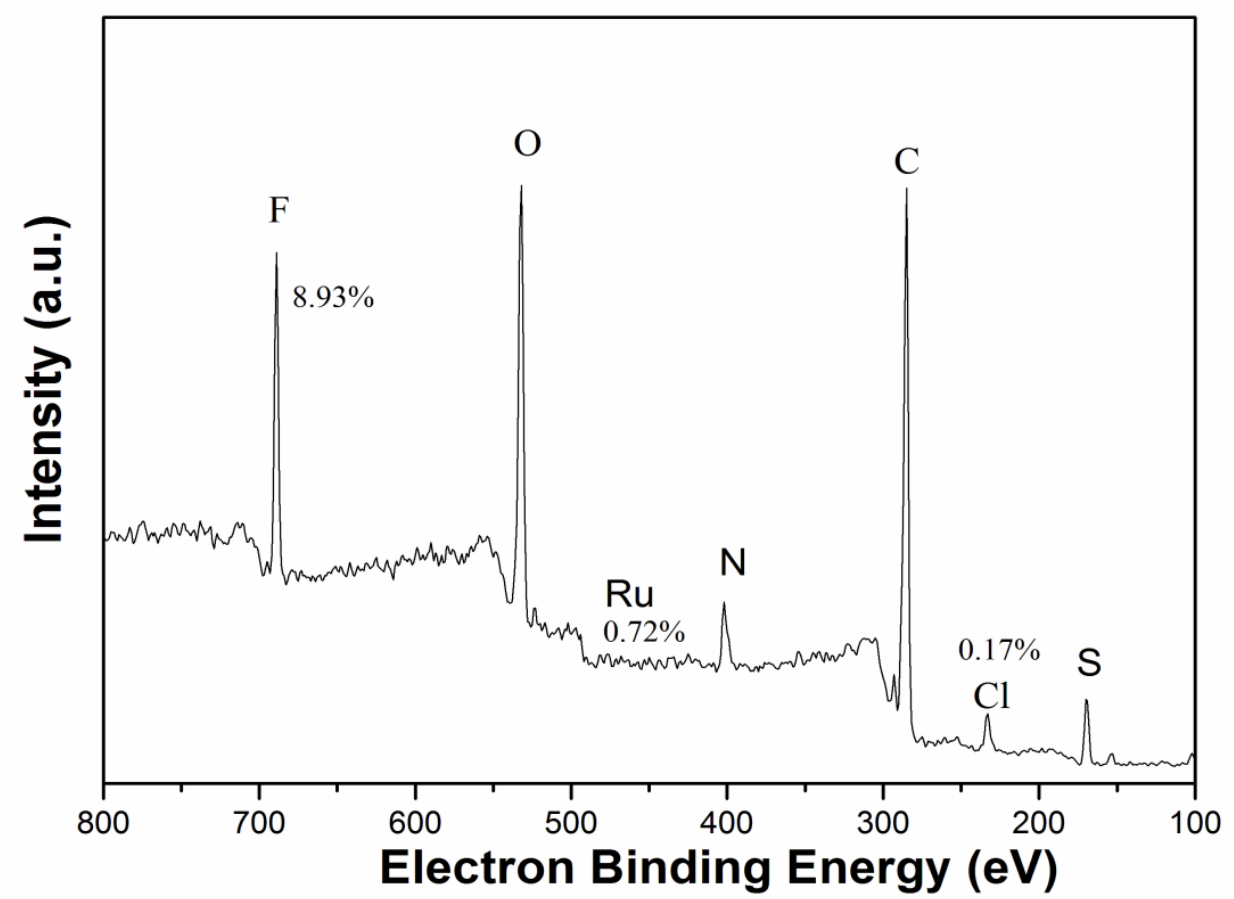

Figure. S13 XPS spectra of Cat-3 after nine cycles.

\section{Analytical data of ATH products for Cat-3 ${ }^{[2-5]}$}




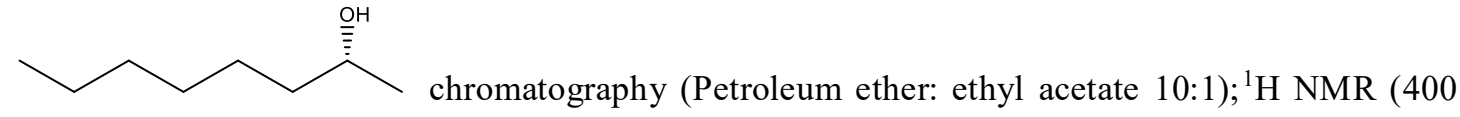
MHz, Chloroform- $d$ ) $\delta 3.79(\mathrm{~h}, J=6.0 \mathrm{~Hz}, 1 \mathrm{H}), 1.57-1.37(\mathrm{~m}, 2 \mathrm{H}), 1.29(\mathrm{q}, J=4.6 \mathrm{~Hz}, 8 \mathrm{H})$, $1.18(\mathrm{dd}, J=6.2,1.3 \mathrm{~Hz}, 3 \mathrm{H}), 0.88(\mathrm{t}, J=6.4 \mathrm{~Hz}, 3 \mathrm{H})$.; ${ }^{19} \mathrm{~F}$ NMR for determining the ee $(376$ $\mathrm{MHz}$, Chloroform-d) $\delta$ : - 69.01 (major, S-enantiomer), - 71.58 (minor, R-enantiomer).

${ }^{19} \mathrm{~F}$ NMR: racemates (above), chiral product (below)

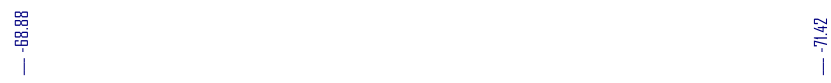

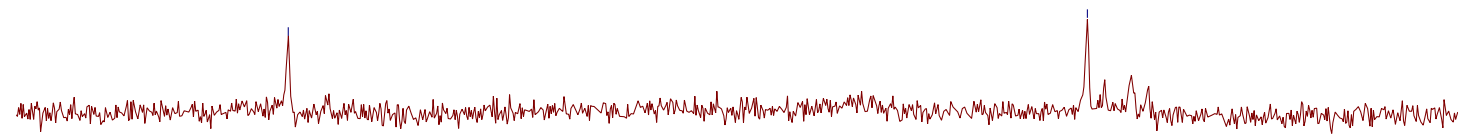

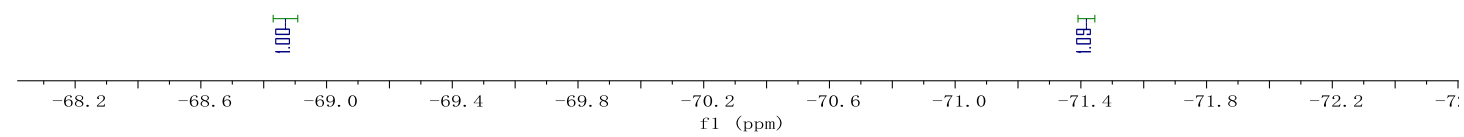




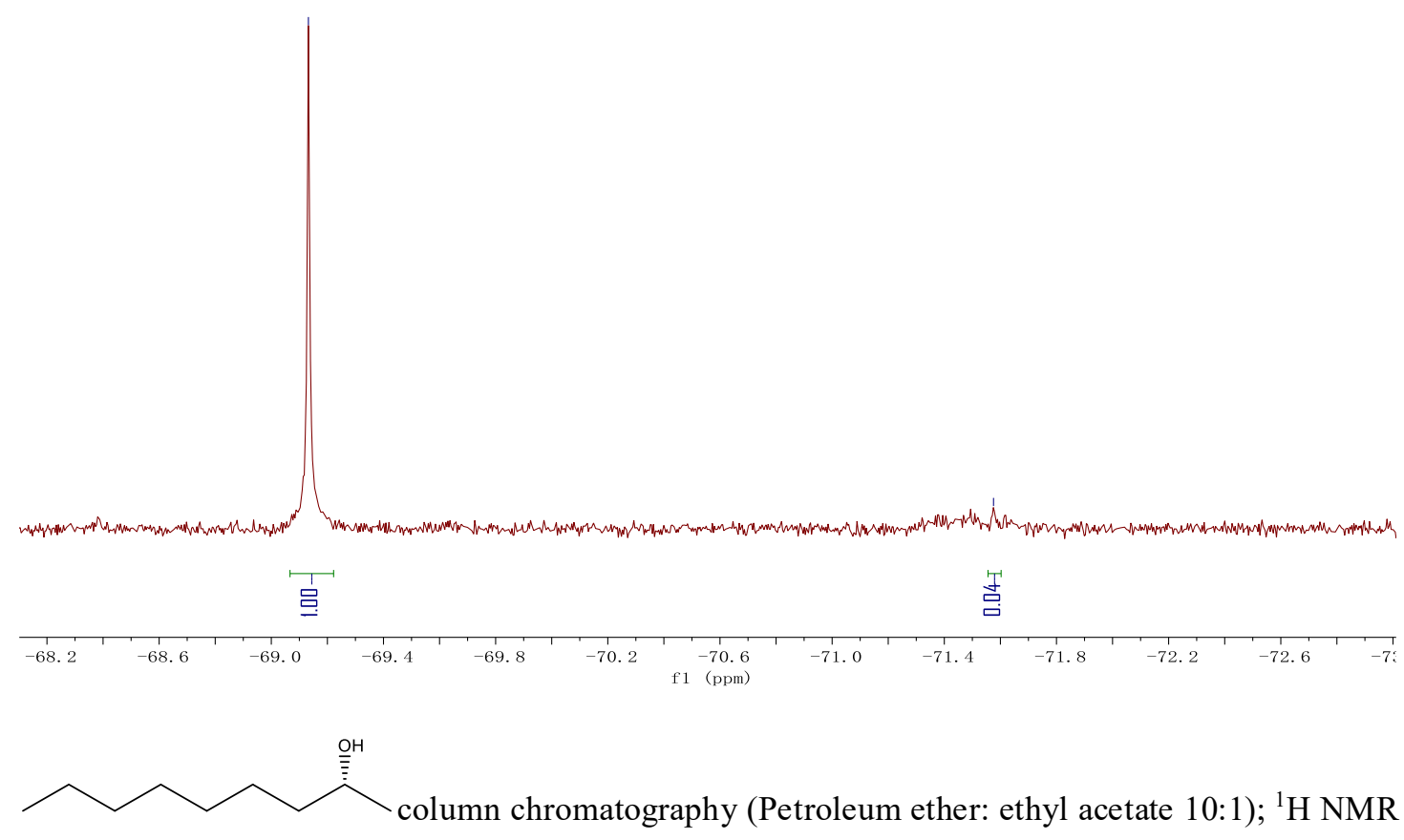
(376 MHz, Chloroform- $d$ ) $\delta 3.79$ (h, $J=6.0 \mathrm{~Hz}, 1 \mathrm{H}), 1.50-1.37$ (m, 2H), 1.29 (q, $J=5.3 \mathrm{~Hz}$, $10 \mathrm{H}), 1.19(\mathrm{~d}, J=6.2 \mathrm{~Hz}, 3 \mathrm{H}), 0.88(\mathrm{t}, J=6.6 \mathrm{~Hz}, 3 \mathrm{H}) . ;{ }^{19} \mathrm{~F}$ NMR for determining the ee $(400$ MHz, Chloroform- $d$ ) $\delta$ : - 69.01 (major, S-enantiomer), - 71.42 (minor, R-enantiomer).

${ }^{19}$ F NMR: racemates (above), chiral product (below) 


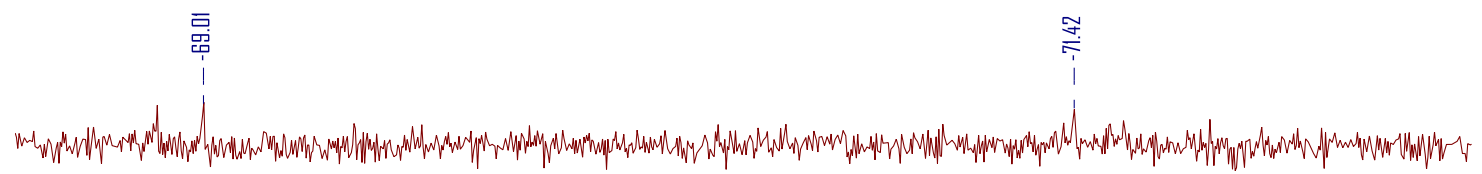

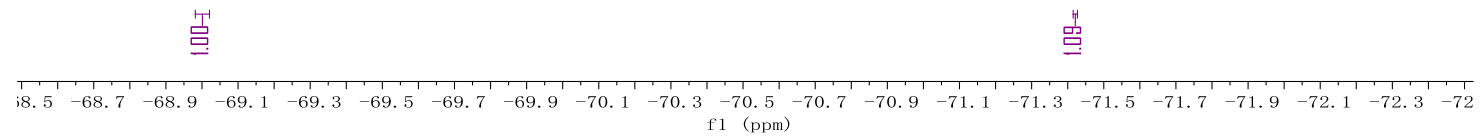

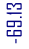

崇

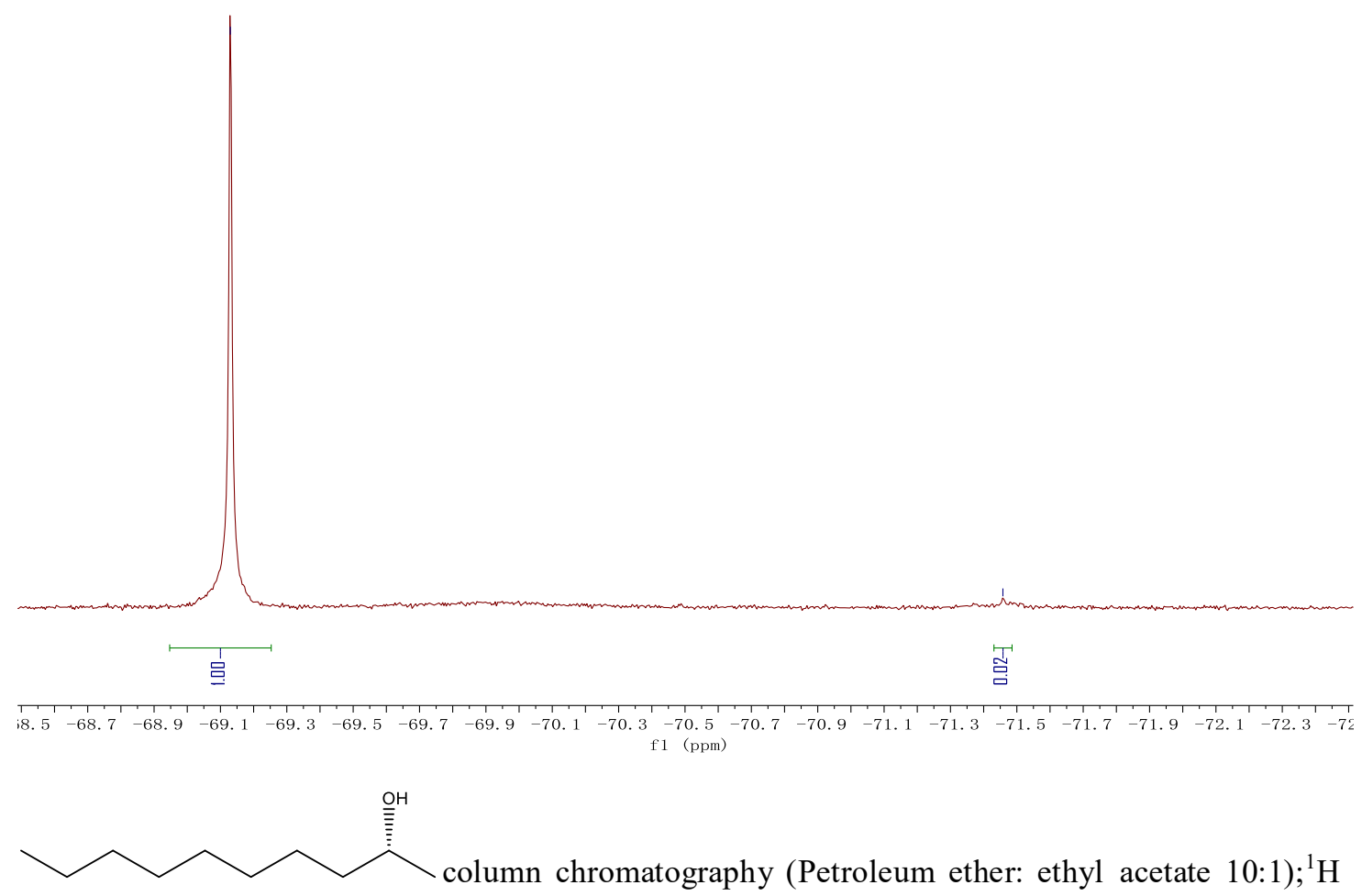

NMR (400 MHz, Chloroform- $d$ ) $\delta 3.78(\mathrm{p}, J=6.3 \mathrm{~Hz}, 1 \mathrm{H}), 1.45(\mathrm{dt}, J=20.2,13.5 \mathrm{~Hz}, 2 \mathrm{H}), 1.27$ $(\mathrm{d}, J=6.8 \mathrm{~Hz}, 16 \mathrm{H}), 1.18(\mathrm{~d}, J=6.2 \mathrm{~Hz}, 3 \mathrm{H}), 0.88(\mathrm{t}, J=6.7 \mathrm{~Hz}, 3 \mathrm{H}){ }^{19} \mathrm{~F}$ NMR for determining 
the ee (400 MHz, Chloroform- $d$ ) $\delta:-70.50$ (major, S-enantiomer), - 71.58 (minor, R-enantiomer).

${ }^{19}$ F NMR: racemates (above), chiral product (below)

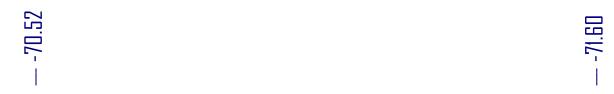

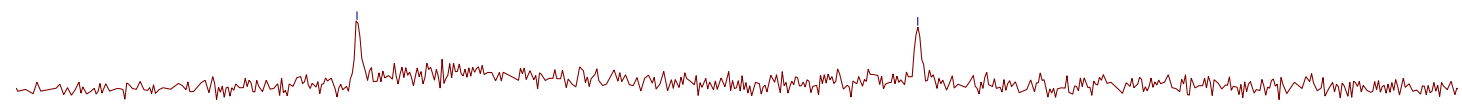

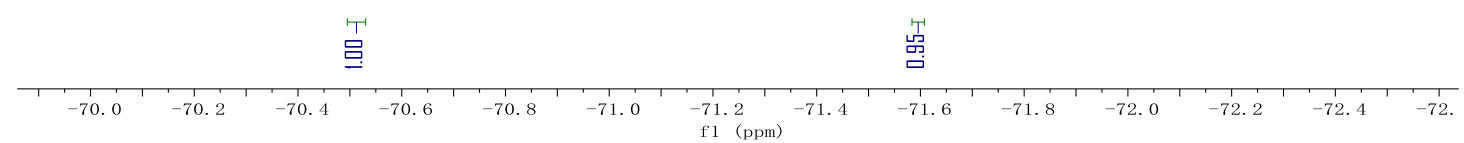

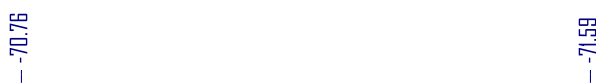

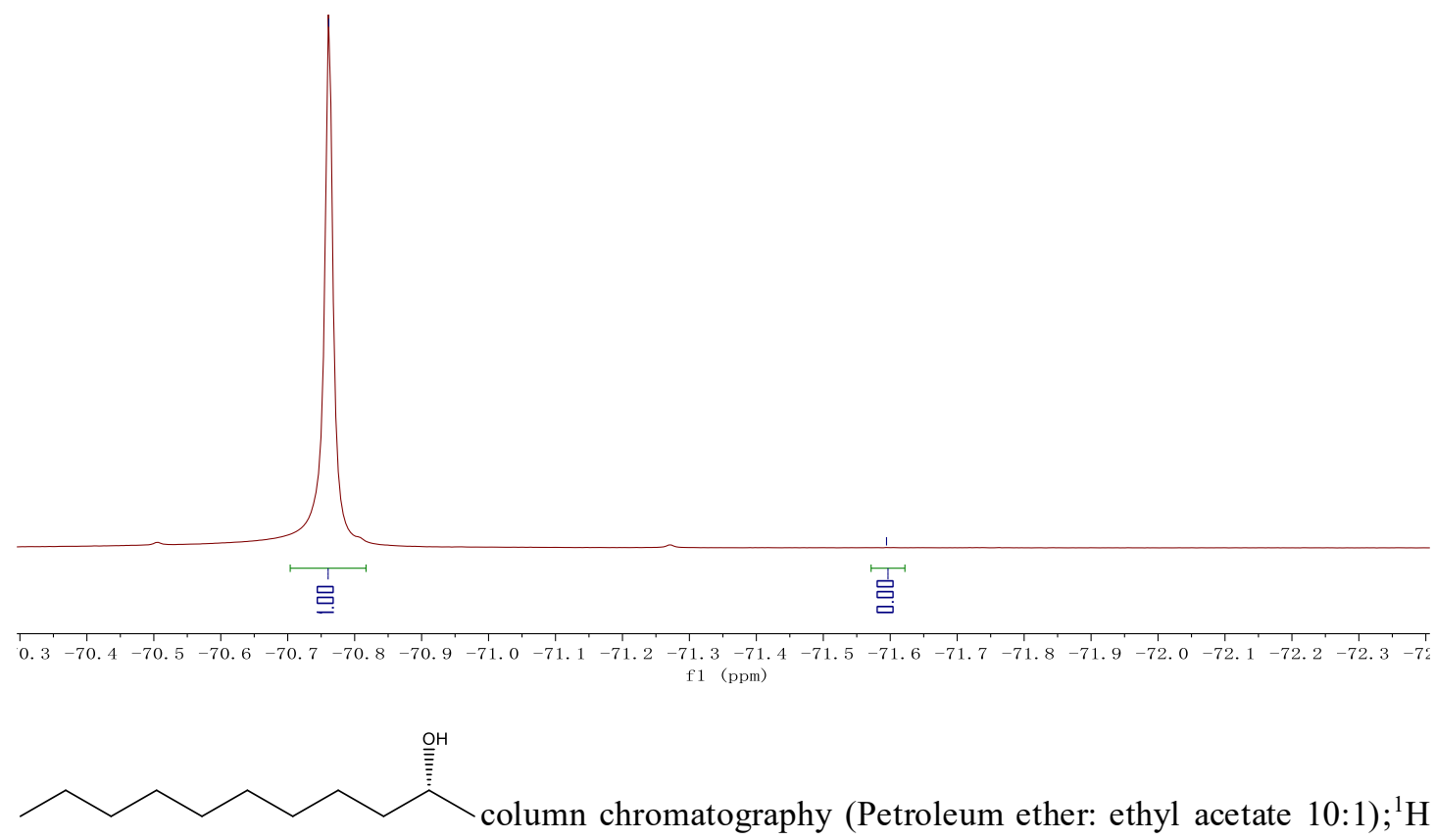


NMR (400 MHz, Chloroform- $d$ ) $\delta 3.78(\mathrm{p}, J=6.3 \mathrm{~Hz}, 1 \mathrm{H}), 1.45(\mathrm{dt}, J=20.2,13.5 \mathrm{~Hz}, 2 \mathrm{H}), 1.27$ $(\mathrm{d}, J=6.8 \mathrm{~Hz}, 16 \mathrm{H}), 1.18(\mathrm{~d}, J=6.2 \mathrm{~Hz}, 3 \mathrm{H}), 0.88(\mathrm{t}, J=6.7 \mathrm{~Hz}, 3 \mathrm{H}){ }^{19} \mathrm{~F}$ NMR for determining the ee (376 MHz, Chloroform- $d$ ) $\delta:-71.43$ (major, S-enantiomer), - 71.48 (minor, R-enantiomer).

${ }^{19} \mathrm{~F}$ NMR: racemates (above), chiral product (below)

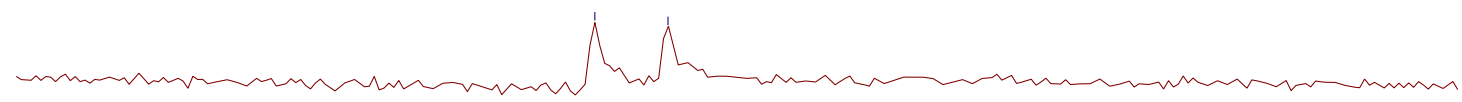

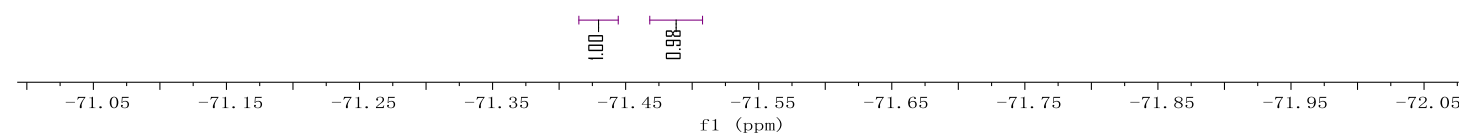

$$
\stackrel{\text { ํ}}{i} \stackrel{\infty}{\stackrel{\infty}{*}}
$$

\section{总 志}


column chromatography (Petroleum ether: ethyl acetate 10:1); ${ }^{1} \mathrm{H}$ NMR (376 MHz, Chloroform-d) $\delta 3.79(\mathrm{~h}, J=6.1 \mathrm{~Hz}, 1 \mathrm{H}), 1.45$ (ddd, $J=25.6,12.2,7.0 \mathrm{~Hz}$, $2 \mathrm{H}), 1.27(\mathrm{~d}, J=8.3 \mathrm{~Hz}, 18 \mathrm{H}), 1.18(\mathrm{dd}, J=6.2,1.7 \mathrm{~Hz}, 3 \mathrm{H}), 0.88(\mathrm{t}, J=6.6 \mathrm{~Hz}, 3 \mathrm{H}) .{ }^{19} \mathrm{~F}$ NMR for determining the ee (400 MHz, Chloroform- $d$ ) $\delta$ : - 71.44 (major, S-enantiomer), - 71.49 (minor, R-enantiomer).

${ }^{19}$ F NMR: racemates (above), chiral product (below)

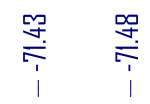

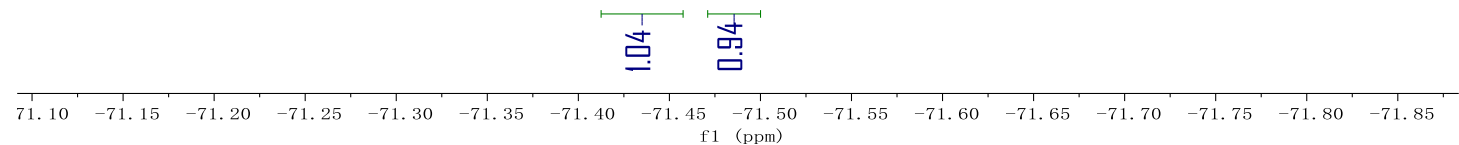




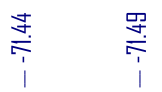
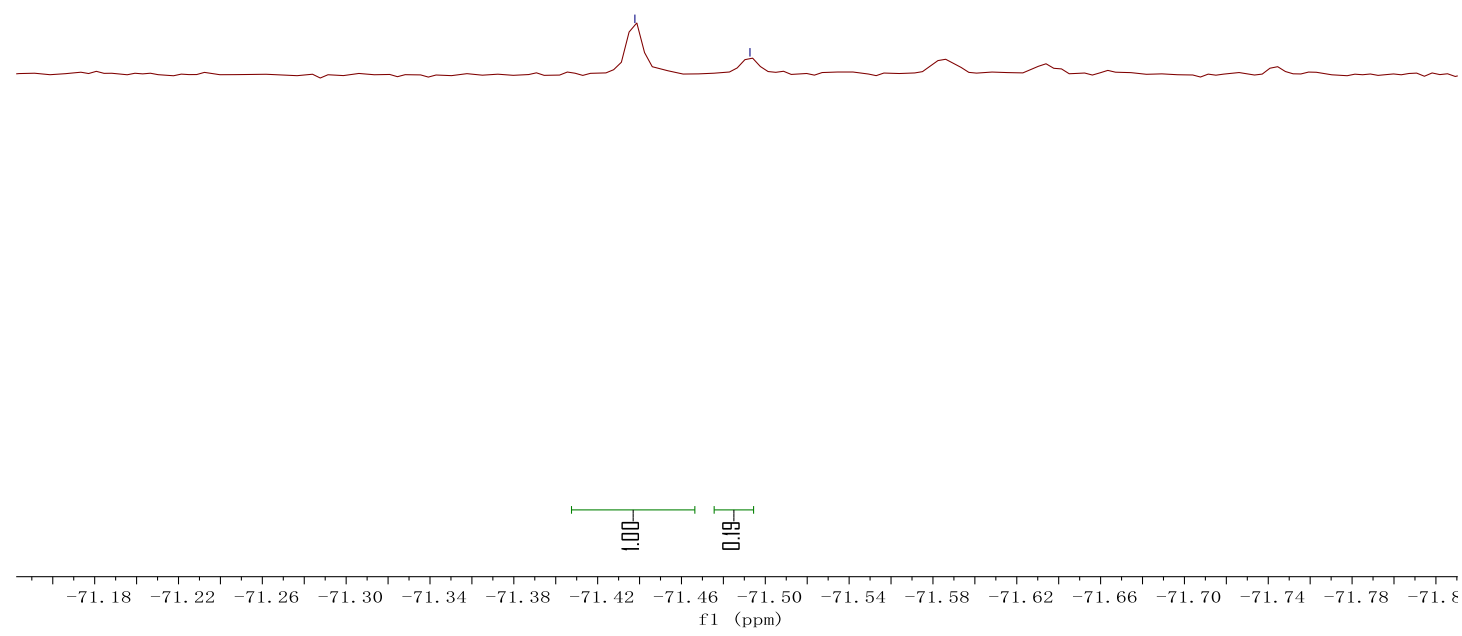

$\overbrace{1}^{H O}$

column chromatography (light petrol: ethyl acetate 10:1); ${ }^{1} \mathrm{H}$ NMR (400 MHz, CDCl3) $\delta 7.39-7.30(\mathrm{~m}, 4 \mathrm{H}), 7.29-7.24(\mathrm{~m}, 1 \mathrm{H}), 4.88(\mathrm{q}, \mathrm{J}=6.5 \mathrm{~Hz}, 1 \mathrm{H}), 2.02(\mathrm{~s}, 1 \mathrm{H}), 1.49(\mathrm{~d}, \mathrm{~J}=6.5$ Hz, 3H). Chiral HPLC analysis: (chiracel diacel OD-H, hexane : 2-propanol 95:5 V/V, 1.0 mL/min, $25^{\circ} \mathrm{C}, \mathrm{UV} 254 \mathrm{~nm}$ ): $\mathrm{t}_{1}=8.75 \mathrm{~min}$ (major, R-enantiomer), $\mathrm{t}_{2}=10.00 \mathrm{~min}$ (minor, S-enantiomer).

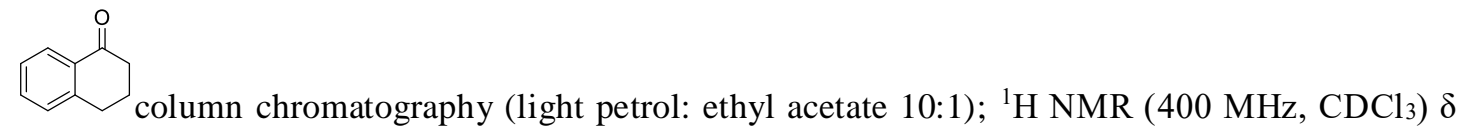
$7.48-7.38(\mathrm{~m}, 1 \mathrm{H}), 7.24-7.16(\mathrm{~m}, 2 \mathrm{H}), 7.11(\mathrm{dd}, J=5.6,3.4 \mathrm{~Hz}, 1 \mathrm{H}), 4.89-4.67(\mathrm{~m}, 1 \mathrm{H}), 2.84$ $(\mathrm{dt}, J=16.4,5.3 \mathrm{~Hz}, 1 \mathrm{H}), 2.79-2.67(\mathrm{~m}, 1 \mathrm{H}), 2.04-1.75(\mathrm{~m}, 5 \mathrm{H})$. Chiral HPLC analysis: (chiracel diacel OD-H, hexane : 2-propanol 95:5 V/V, $1.0 \mathrm{~mL} / \mathrm{min}, 25^{\circ} \mathrm{C}$, UV $254 \mathrm{~nm}$ ): $\mathrm{t}_{1}=9.06$ $\min$ (major, R-enantiomer), $\quad t_{2}=13.80$ min (minor, S-enantiomer).

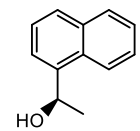

column chromatography (light petrol: ethyl acetate 10:1); ${ }^{1} \mathrm{H}$ NMR $\left(400 \mathrm{MHz}, \mathrm{CDCl}_{3}\right) \delta$ $8.13(\mathrm{~d}, J=8.3 \mathrm{~Hz}, 1 \mathrm{H}), 7.99-7.82(\mathrm{~m}, 1 \mathrm{H}), 7.79(\mathrm{~d}, J=8.2 \mathrm{~Hz}, 1 \mathrm{H}), 7.69(\mathrm{~d}, J=7.1 \mathrm{~Hz}, 1 \mathrm{H})$, $7.59-7.41(\mathrm{~m}, 3 \mathrm{H}), 5.70(\mathrm{q}, J=6.4 \mathrm{~Hz}, 1 \mathrm{H}), 1.69(\mathrm{~d}, J=6.5 \mathrm{~Hz}, 3 \mathrm{H}), 1.38(\mathrm{t}, J=7.3 \mathrm{~Hz}, 1 \mathrm{H})$. 
Chiral HPLC analysis: (chiracel diacel OD-H, hexane: 2-propanol 95:5 V/V, $1.0 \mathrm{~mL} / \mathrm{min}, 25^{\circ} \mathrm{C}$, UV $254 \mathrm{~nm}$ ): $\mathrm{t}_{1}=18.42 \min$ (major, R-enantiomer), $\mathrm{t}_{2}=27.48 \mathrm{~min}$ (minor, S-enantiomer).<smiles>Oc1ccc(F)cc1</smiles>

column chromatography (light petrol: ethyl acetate 10:1); ${ }^{1} \mathrm{H}$ NMR $\left(400 \mathrm{MHz}, \mathrm{CDCl}_{3}\right) \delta$ $7.36-7.26(\mathrm{~m}, 4 \mathrm{H}), 4.88(\mathrm{qd}, J=6.5,2.2 \mathrm{~Hz}, 1 \mathrm{H}), 2.08(\mathrm{~d}, J=3.5 \mathrm{~Hz}, 1 \mathrm{H}), 1.47(\mathrm{dd}, J=6.5,1.5$ $\mathrm{Hz}, 3 \mathrm{H}$ ). Chiral HPLC analysis: (chiracel diacel OD-H, hexane: 2-propanol 95:5 V/V, $1.0 \mathrm{~mL} / \mathrm{min}$, $\left.25^{\circ} \mathrm{C}, \mathrm{UV} 254 \mathrm{~nm}\right): \mathrm{t}_{1}=12.26$ min major, R-enantiomer), $\mathrm{t}_{2}=13.52 \mathrm{~min}$ (minor, S-enantiomer).

NMR spectra of ATH products

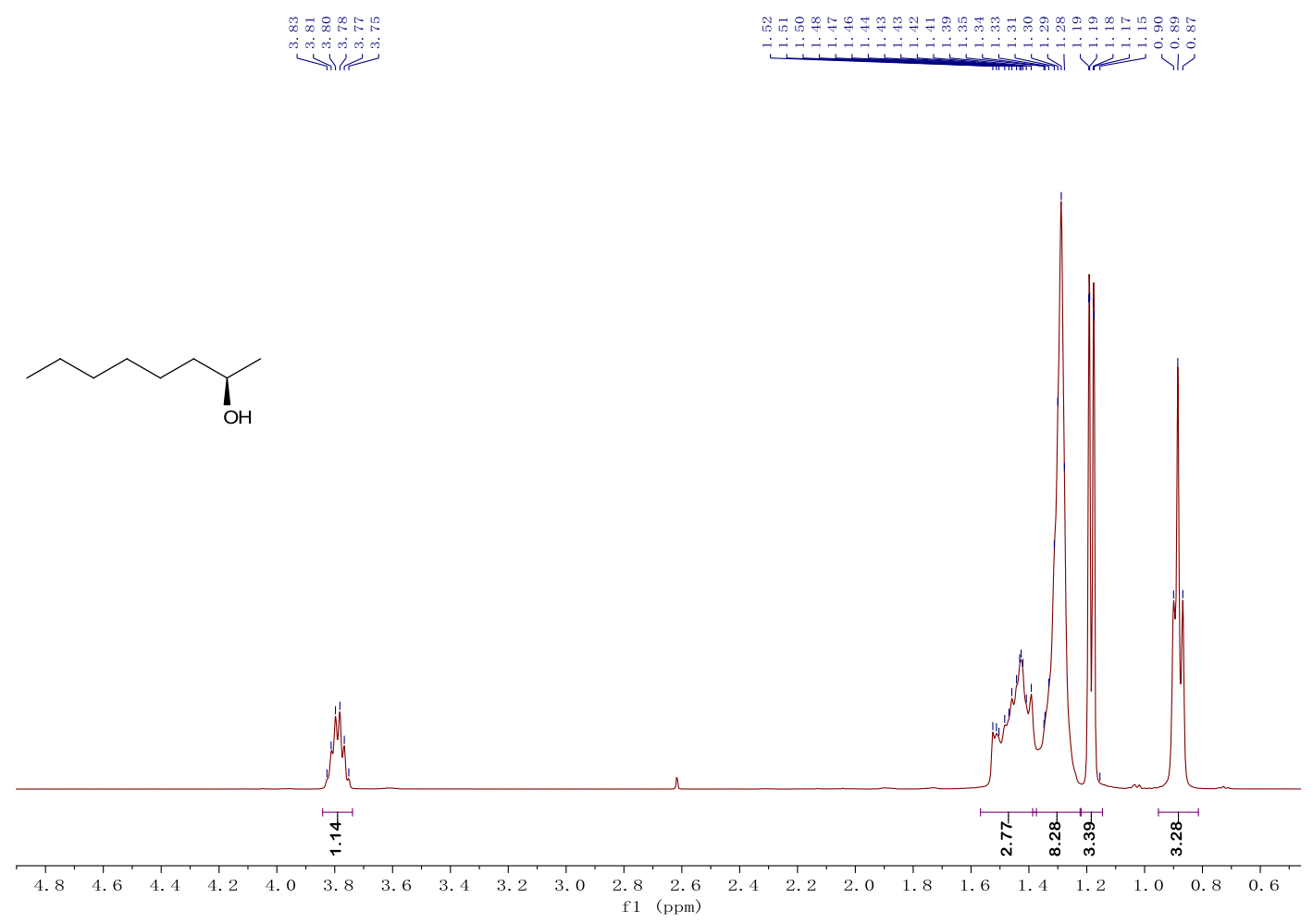


$\overbrace{\mathrm{OH}}$
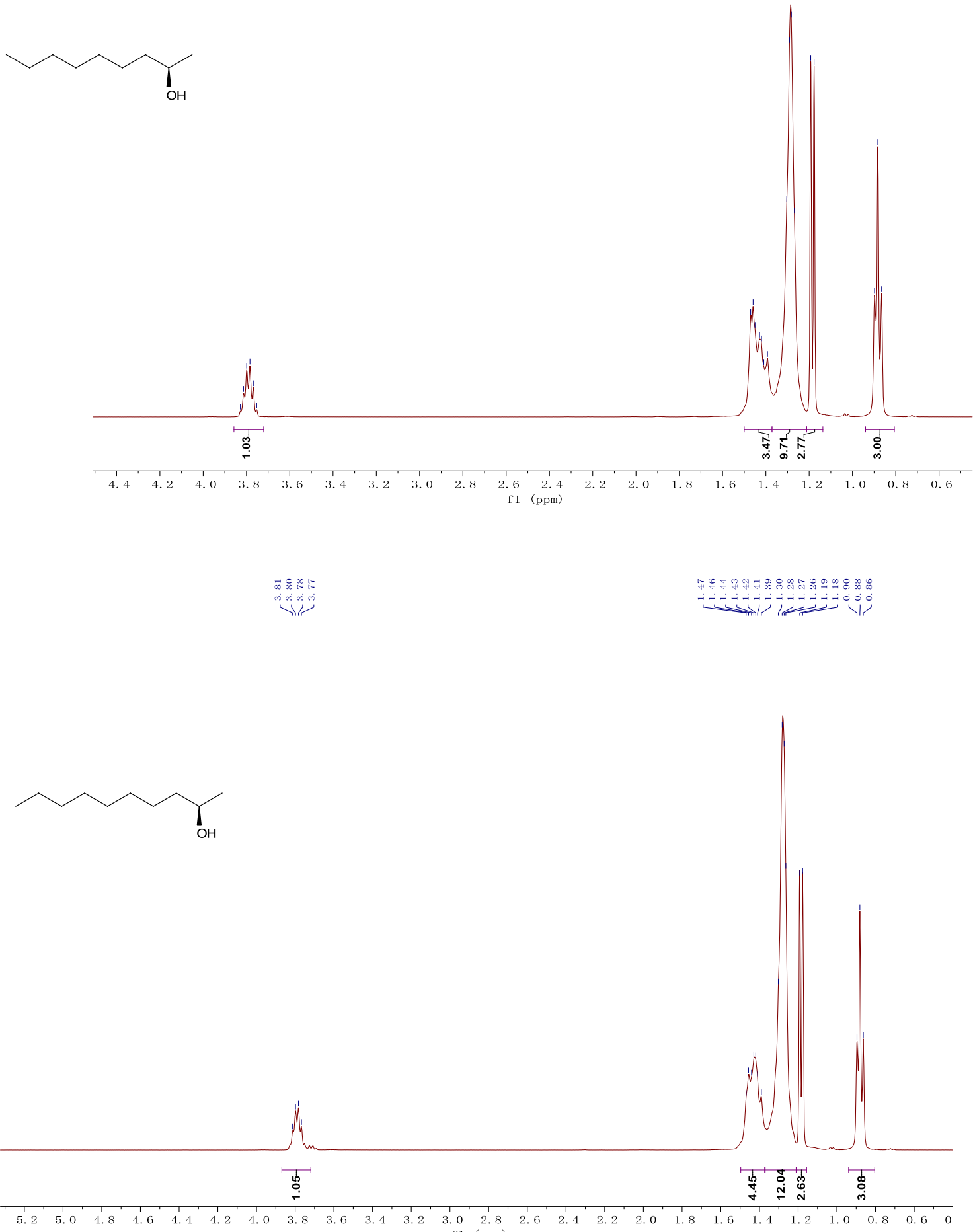

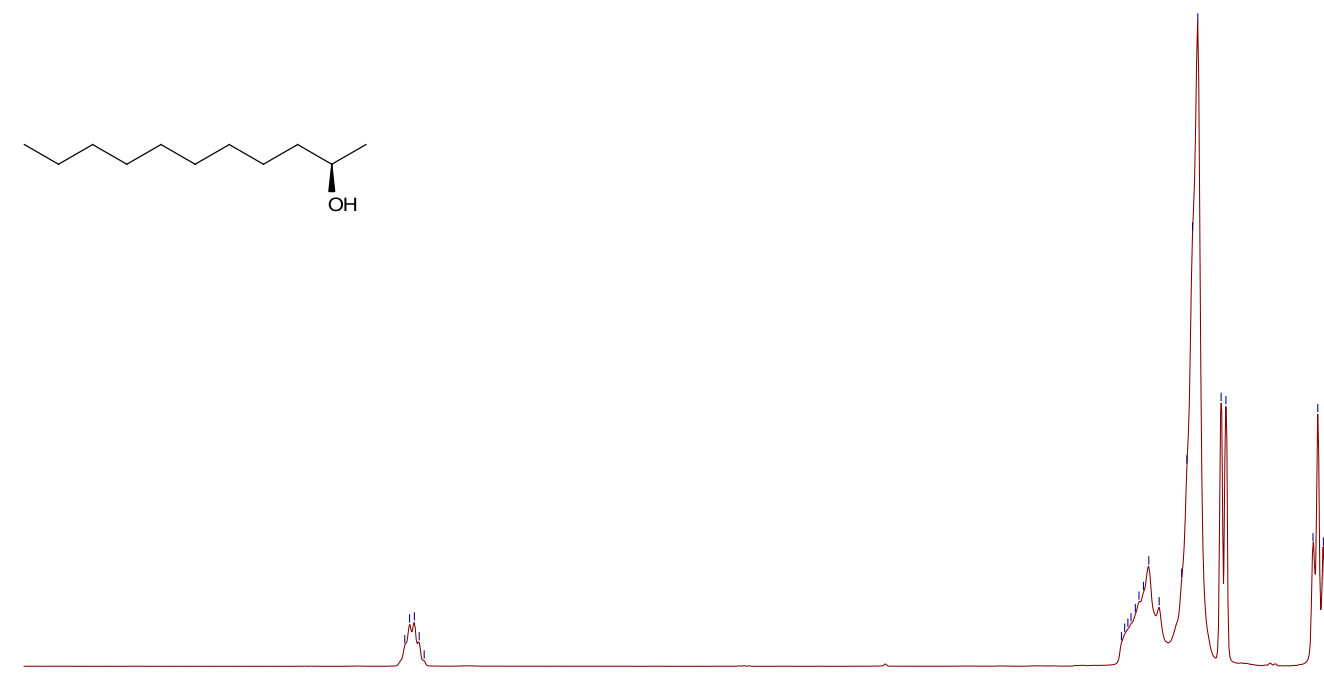

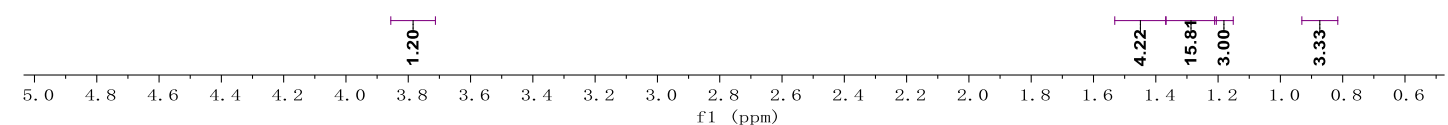

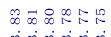

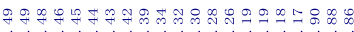

$\underbrace{\infty}$

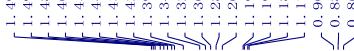
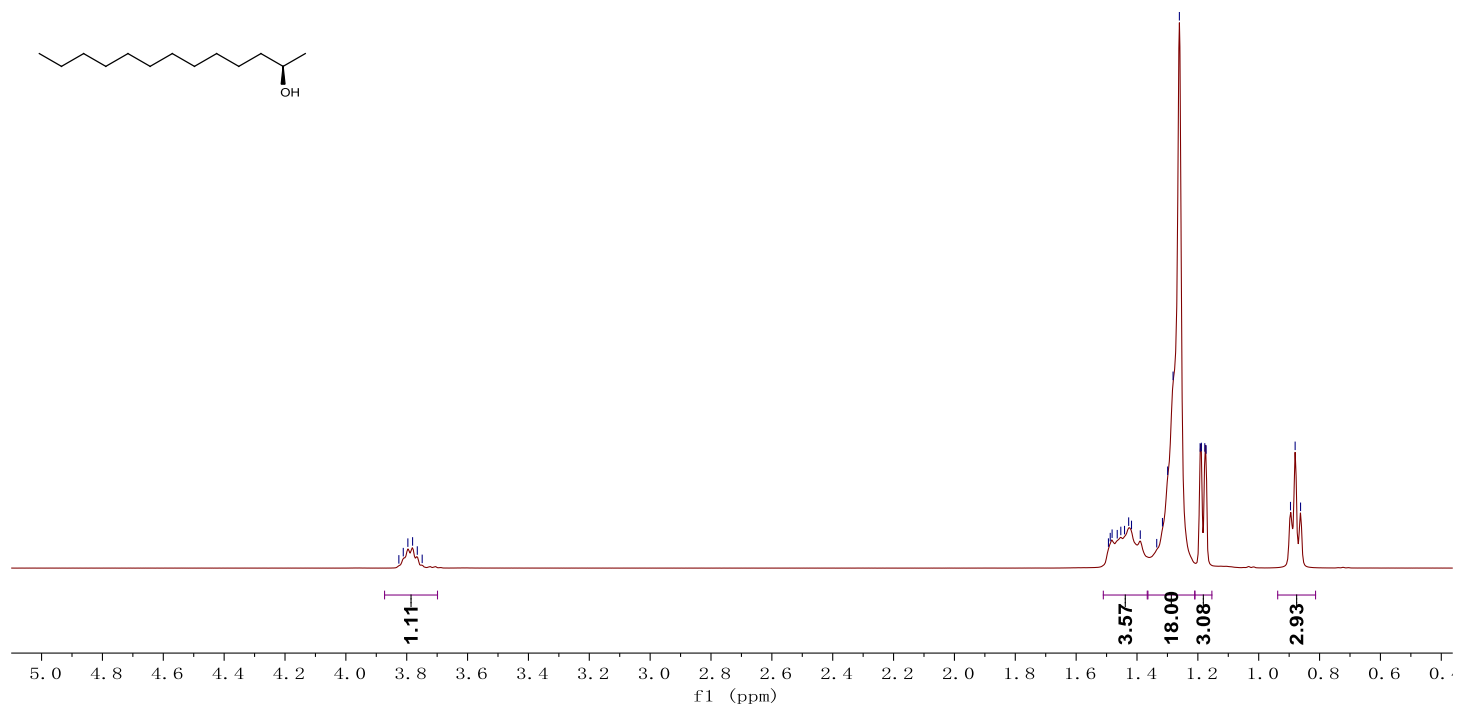


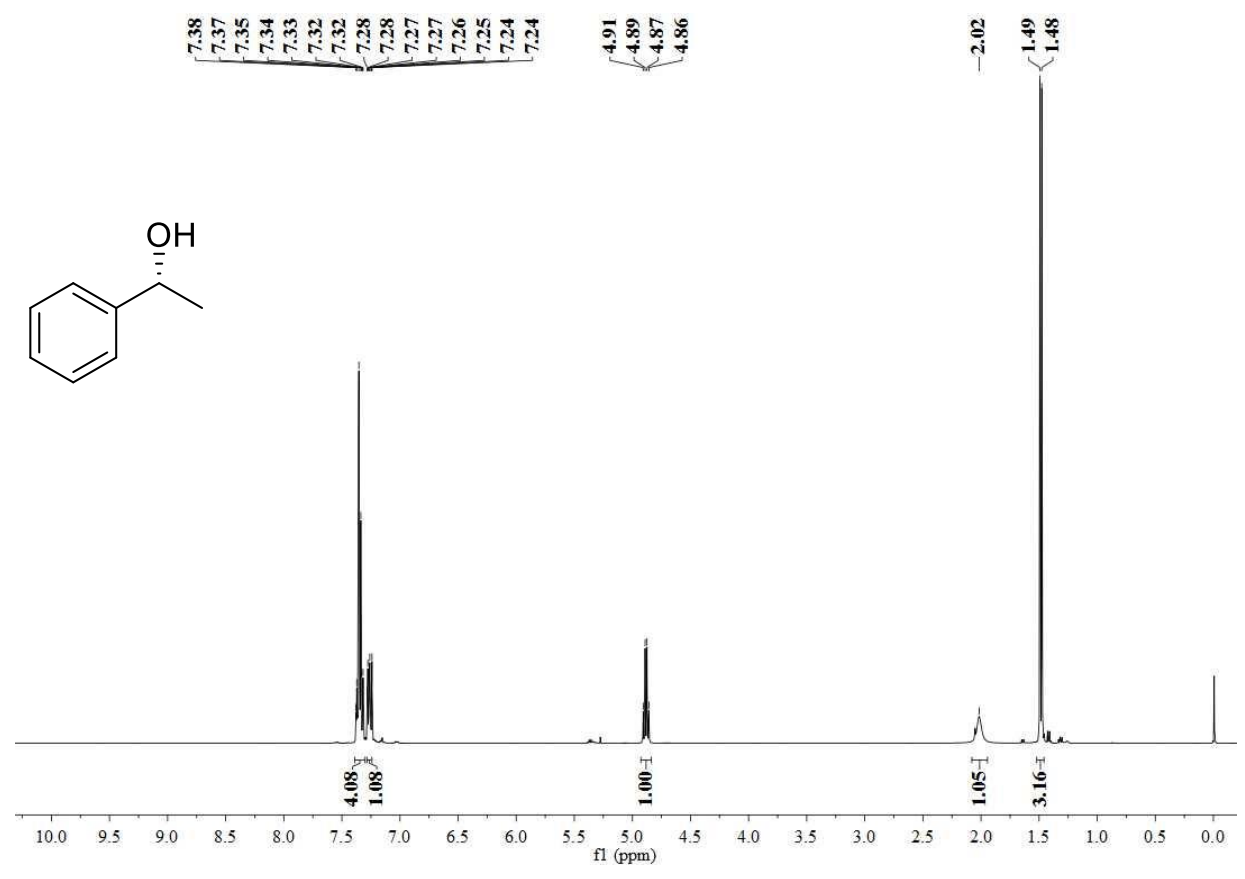

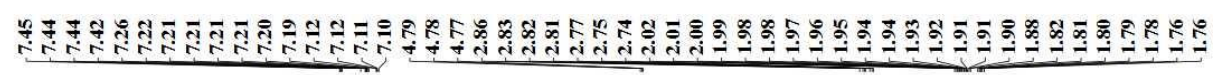

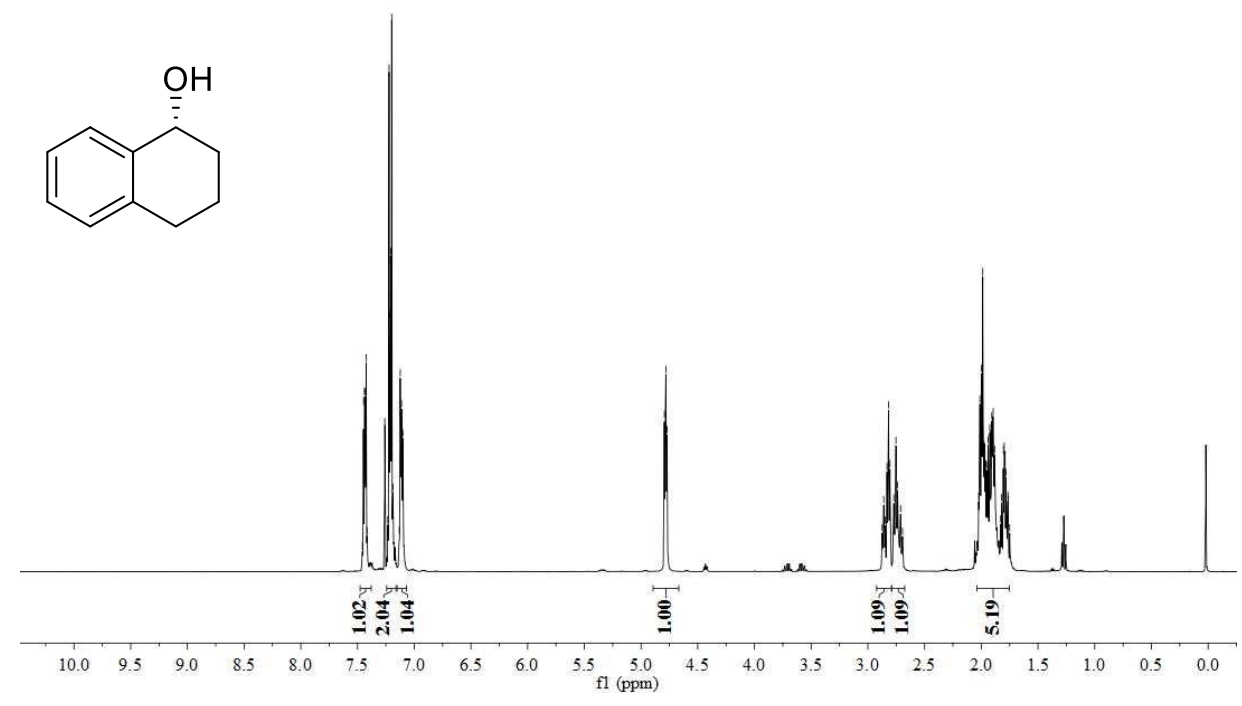



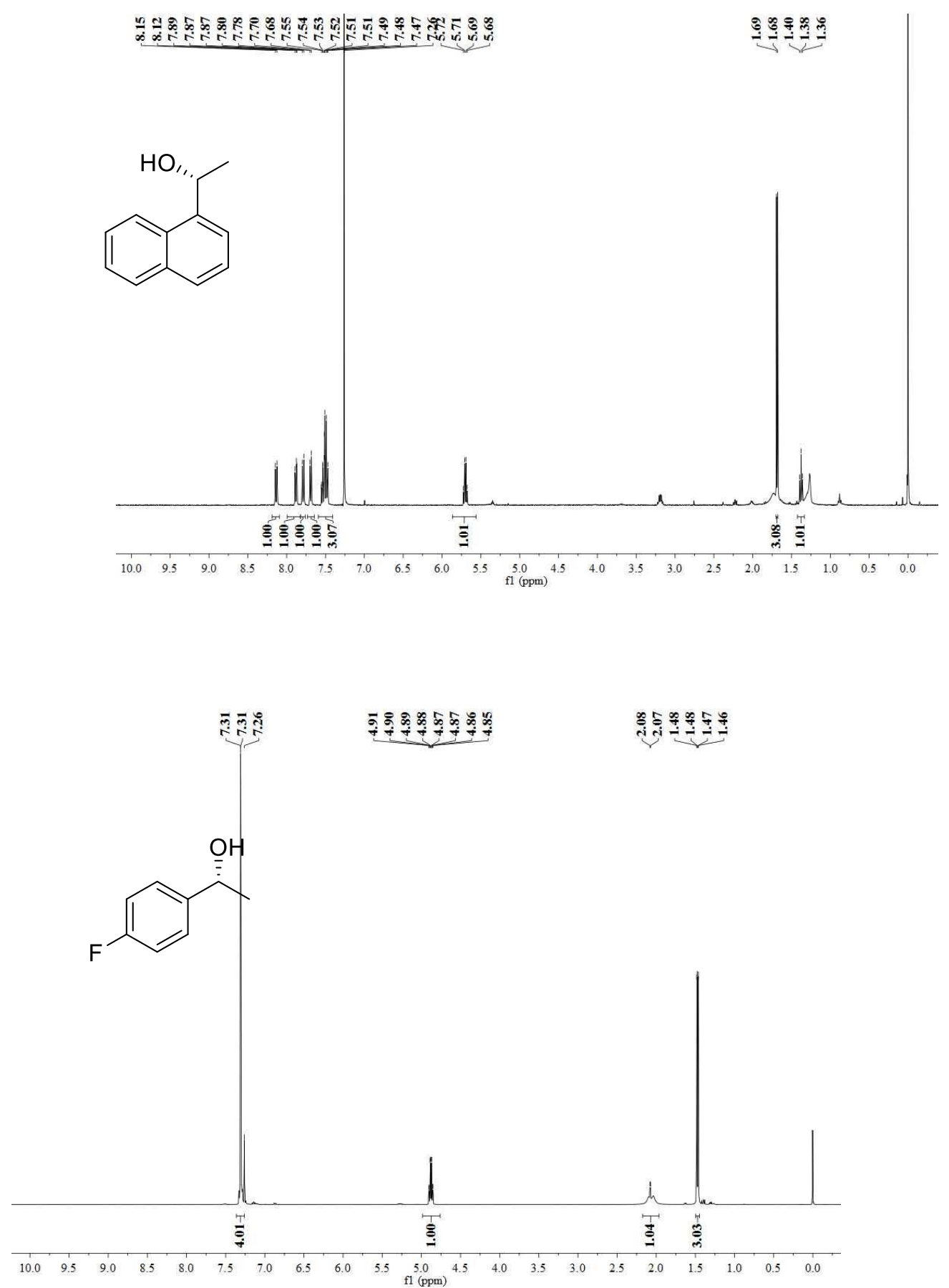

\section{References}

(1) Li, X.; Lv, C.; Jia, X.; Cheng, M.; Wang, K.; Hu, Z. Nanoparticle Based on Poly(Ionic Liquid) as an Efficient Solid Immobilization Catalyst for Aldol Reaction and Multicomponent Reaction in Water. ACS Appl Mater Interfaces. 2017, 9, 827-835.

(2) Pálvölgyi, Á. M.; Bitai, J.; Zeindlhofer, V.; Schröder, C.; Bica, K. Ion-Tagged Chiral Ligands for Asymmetric Transfer Hydrogenations in Aqueous Medium. ACS Sustainable Chemistry \& Engineering. 2019, 7, 3414-3423. 
(3) Inagaki, T.; Ito, A.; Ito, J.-i.; Nishiyama, H. Asymmetric Iron-Catalyzed Hydrosilane Reduction of Ketones: Effect of Zinc Metal upon the Absolute Configuration. Angew. Chem. Int. Ed., 2010, 49, 9384-9387.

(4) Mourad, B.; Saoussen, Z.; Jacqueline, C.; Jean-Claude, F.; Louisa, A.Z. Screening method for the evaluation of asymmetric catalysts for thereduction of aliphatic ketones. Tetrahedron Lett., 2011, 52, 1485-1489.

(5) Nakamura, K.; Matsuda, T. Asymmetric Reduction of Ketones by the Acetone Powder of Geotrichum candidum. J. Org Chem., 1998, 63 (24), 8957-8964. 